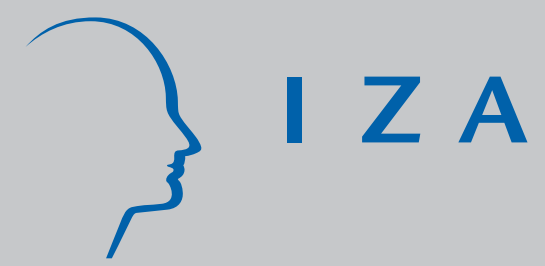

IZA DP No. 4331

Gender Gaps across the Earnings Distribution in Britain: Are Women Bossy Enough?

Yekaterina Chzhen

Karen Mumford

July 2009 


\title{
Gender Gaps across the Earnings Distribution in Britain: Are Women Bossy Enough?
}

\author{
Yekaterina Chzhen \\ University of York
}

Karen Mumford

University of York and IZA

Discussion Paper No. 4331

July 2009

IZA

P.O. Box 7240

53072 Bonn

Germany

Phone: +49-228-3894-0

Fax: +49-228-3894-180

E-mail: iza@iza.org

\begin{abstract}
Any opinions expressed here are those of the author(s) and not those of IZA. Research published in this series may include views on policy, but the institute itself takes no institutional policy positions.

The Institute for the Study of Labor (IZA) in Bonn is a local and virtual international research center and a place of communication between science, politics and business. IZA is an independent nonprofit organization supported by Deutsche Post Foundation. The center is associated with the University of Bonn and offers a stimulating research environment through its international network, workshops and conferences, data service, project support, research visits and doctoral program. IZA engages in (i) original and internationally competitive research in all fields of labor economics, (ii) development of policy concepts, and (iii) dissemination of research results and concepts to the interested public.
\end{abstract}

IZA Discussion Papers often represent preliminary work and are circulated to encourage discussion. Citation of such a paper should account for its provisional character. A revised version may be available directly from the author. 


\section{ABSTRACT \\ Gender Gaps across the Earnings Distribution in Britain: Are Women Bossy Enough?*}

This paper investigates gender differences between the log wage distributions of fullime British employees in the public and private sectors. After allowing for positive selection into full-time employment by women, we find significant and substantial gender earnings gaps, and evidence of glass ceilings, in both sectors. The earnings gaps amongst the higher income earners are found to be related to there being a scarcity of senior women in high skilled, white-collar occupations, especially in the public sector.

JEL Classification: J3, J7

Keywords: gender, earnings, wage-gap, selection, distribution

Corresponding author:

Karen Mumford

Department of Economics and Related Studies

University of York

Heslington York YO10 5DD

United Kingdom

E-mail: kam9@york.ac.uk

\footnotetext{
${ }^{*}$ We thank the BHPS sponsors - the Economic and Social Research Council, the ISER and the Data Archive (both at the University of Essex) - for allowing access to the data. We are also grateful for helpful advice and/or comments from Jim Albrecht, Olivier Bargain, Jonathan Bradshaw, Kath Kiernan, Blaise Melly, Catia Nicodemo, Steve Palmer, Peter N. Smith, Susan Vroman, Aico van Vuuren and from participants at the December WPEG meeting 2008. They are not responsible for any of the findings or claims made in the paper.
} 
The decline in the gender earnings gap in Britain has been dramatic and substantially larger than that experienced in the US (Blau and Kahn, 2003). ${ }^{1}$ The mean hourly gender earnings gap amongst full-time workers in Britain was 37\% when the Equal Pay Act was passed in $1970^{2}$, 23\% in 1990, and 18\% in 2000 (McRae, 2008; 179). Nevertheless, Britain's rate of change has lagged behind many of her European contemporaries (Wilborn, 1991) and a substantial and persistent earnings gap still exists between male and female employees (Connolly and Gregory, 2008; Manning and Petrongolo, 2008; Mumford and Smith, 2007 and 2009).

In the last decade researchers have began to make use of the exceptionally good quality earnings information available in some data sets to analyse the gender gap across the entire wage distribution ${ }^{3}$. These studies provide a much more detailed insight into gender earnings gap and special emphasis has been placed on the findings of relatively larger gender gaps amongst higher earners (the so called 'glass ceiling effect') and amongst low earners (the 'sticky floors effect'). Similar to the familiar Oaxaca (1973) and Blinder (1973) decomposition of the gender earning gap at the mean into the portion attributable to the differences in individual characteristics (the 'explained' component) and the portion attributable to the differences in returns to these characteristics (the 'unexplained' component), the quantile regression framework has been employed to enable analogous decompositions across the wage distribution (Machado and Mata, 2005). The Machado-Mata (MM) decomposition (across the wage distribution) methodology has been further developed to account for sample selection, such as the non random presentation of women in employment (Heckman 1979; Buchinsky 1998; Albrecht et al., 2007; Melly, 2006; Nicodemo, 2009). ${ }^{4}$

Nicodemo (2009) decomposes the pay gap between husbands and wives across the earnings distribution after allowing for self-selection of married women

\footnotetext{
${ }^{1}$ This literature on gender wage inequality is well established (see surveys by Altonji and Blank, 1999; Weichselbaumer and Winter-Ebman, 2005).

${ }^{2}$ There has subsequently been a series of legislation directly seeking to lower the gap between male and female earnings (Dickens, 2007) and, perhaps, more indirectly lowering the gap such as the introduction of the national minimum wage in 1999.

${ }^{3}$ These studies include quantile regression methods; for example, see Albrecht et al., (2003) for Sweden; Baron and Cobb-Clark (2008) for Australia; and de la Rica et al., (2008) for Spain. In the UK these studies are rare, a recent example for Europe which includes data for Britain is provided in Arulampalam et al., (2007), using the European Community Household Panel.

${ }^{4}$ An alternative bounded approach is provided by Blundell et al, 2007.
} 
into employment in five Mediterranean countries ${ }^{5}$, using data from the ECHP 2001 and the EU Statistics on Income and Living Conditions (EU-SILC) 2006. She finds substantial wage gaps in each country, with the greatest portion being due to differences in rewards, and that sticky floors are more predominant than glass ceilings. She does not include Britain in her study.

Albrecht et al., (2007) decompose the gender gap along the wage distribution among full-time workers in the Netherlands, using 1992 data. They document the presence of a glass ceiling effect, as the gender gap is positive along the distribution but is largest at the highest quantiles. The majority of the gender pay gap in their study is attributed to differences in rewards to the labour market characteristics of male and female workers. Albrecht et al., (2007) also account for women's selection into full-time work. They find that if all women worked full-time, the average log wage gap between male and female workers would have been higher in the Netherlands; with the majority of the positive selection effect being associated with full-time working women's observed characteristics.

In this paper we use the quantile regression decomposition method (Machado and Mata, 2005) to study the gender wage gap in log hourly earnings across the distribution amongst full-time workers (private and public sector) in Britain including allowance for possible selection of women into full-time employment (Albrecht et al., 2007; Nicodemo, 2009). Several recent studies have revealed substantially different wage outcomes in the public and private sectors in Britain (Burgess and Ratto, 2003; Disney and Gosling, 2003; Arulampalam et al., 2007; Chatterji et al., 2008). There are a range of possible explanations in the literature, such the private sector attracting less risk averse employees (Pfiefer, 2008); offering greater incentives conducive to higher pay (Burgess and Ratto, 2003); or being less inclined to implement equal pay legislation (Gregory and Borland, 1999; Chatterji et al, 2008). To account more fully for possible differences in the determinants of gender wage gaps between the public and private sectors, we estimate models for private and public sector employees separately.

Data and variable selection are discussed in the next section, estimation methods and sample selection are considered in section 2, results for the earnings functions estimations are presented and discussed in section 4, the decompositions of

\footnotetext{
${ }^{5}$ Spain, France, Greece, Italy and Portugal.
} 
the gender wage gaps are addressed in section 4, and conclusions are presented in section 5 .

\section{Wage Data and the Earnings Function}

We use data from the British Household Panel Survey (BHPS) which is a nationally representative, annual sample of private British households. The BHPS was launched in 1991. Each year, individual adult members of households are interviewed over a broad range of socioeconomic topics resulting in a rich and relevant data set. The latest wave of the BHPS data (2006/7) was released in late September 2008, however, our focus is on 2005/6 wave of data as we are particularly interested in the attitudinal questions which were introduced in that wave and have not been repeated since.

To focus on those who are least likely to be in full-time education or retirement, our sample is restricted to individuals in the 25 to 55 age bracket. We excluded the non-working and part-time employed men from our sample. We also excluded self-employed men and women; the minority of workers with no expected weekly working hours; and those reporting working more than 75 hours per week (including paid overtime). Due to differences in sampling, we did not include individuals from Northern Ireland. Any employed respondents with missing hourly earnings (372 cases) were excluded, as were those with missing data on any of the important labour market or personal characteristics. Our final sample contains observations for 4,223 individuals, of whom 3,695 are waged or salaried workers and 528 are non-working women. Variable definitions and summary statistics for the subsamples of interest are presented in Table 1.

\subsection{The Distribution of Wages in the BHPS}

Our wage measure is the natural logarithm of gross hourly earnings. It is derived from gross monthly pay at last payment and total weekly hours (both measures include paid overtime). Individuals with hourly earnings below $£ 1$ or exceeding $£ 100$ were excluded from the analysis. Men's average hourly wages are substantially higher than women's in Britain (see Table 1): the mean gender earnings gap amongst all full-time workers is 16 log wage points (lwp); 25 lwp in the private sector, and 14 lwp in the public sector.

These mean log wage gaps may, however, hide important differences across the wage distribution, such as those between low earners and high earners. The 
distribution of earnings is considered in greater detail in Figure 1 which plots the estimated kernel densities of men and women's wages for men and women working full-time in the public and private sectors, respectively. The distribution of male wages is essentially symmetric, while the corresponding female distribution is somewhat skewed to the left. The differences between the male and female distributions are more pronounced in the private sector. Figures $2 \mathrm{a}$ and $2 \mathrm{~b}$ plot the raw (unadjusted) difference in log hourly wages between full-time male and female workers at each quantile of the distribution ${ }^{6}$ in the public and private sectors, respectively. In aggregate, the raw gender gap is larger in the private sector, especially so between the $50^{\text {th }}$ and $70^{\text {th }}$ quantiles when the gap can be seen to decline in the public sector. The raw gender gap rises steeply from the $80^{\text {th }}$ quantile upwards in the public sector, however, suggesting the presence of a glass ceiling. In the private sector the gap can be seen to be increasing more steadily across the distribution, again suggesting the presence of a glass ceiling. There does not appear to be a notable sticky floor effect in the raw data for either sector. Simply considering the mean log wage gap would mask these differences in the gender wage gap that occurs across the earnings distribution.

\subsection{The Determinants of Wages}

Most authors have adopted the human capital model as the theoretical basis for the earnings function (Becker, 1962 and 1964; Mincer, 1958). This approach will also be used here. At the individual employee level, it is assumed that wages increase with measures of accumulated skills such as education and work experience. Education is measured here by the highest educational qualification level achieved (see Table 1). We use a continuous variable for the years of actual labour market work experience using the individual's employment history since first leaving full-time education (Halpin 2006). This is a superior measure than the commonly used proxies of potential lifetime work experience (Polacheck, 2006; Regan and Oaxaca, 2008).

We augment the basic human capital variables (education, experience and experience squared) in the earnings function with the inclusion of further explanatory variables: marital status; occupation; having managerial supervisory duties; firm size; and region. As discussed above, we also make allowance for possible sample

\footnotetext{
${ }^{6}$ The 95\% confidence interval is estimated via bootstrapping with 100 repetitions (see Melly, 2006).
} 
selection of women into full-time employment in the estimation of the earnings functions below. This involves estimation of employment probabilities. To identify the selection effect, we include information on the presence of children in the household and on the worker's response to the attitudinal statement "the family suffers if the mother works full-time”.

Table 1 reveals notable differences between male and female workers in terms of these additional characteristics. In summary, men are more likely to work in the private sector than are women. Men are also disproportionately represented in the managerial occupation as well as skilled trades and operatives, while women are overrepresented in administrative/secretarial occupations and in personal services. The importance of occupation in the determination of wages for full-time women relative to part-time women has recently been shown to be important in Britain (Connolly and Gregory, 2008; Manning and Petrongolo, 2008). We believe that occupation will also be important for the pay of full-time men relative to full-time women (Mumford and Smith, 2007 and 2009). Furthermore, differences in the number of men and women who say they carry out managerial duties may also be an important determinant of relative pay. Men are more likely to carry out managerial duties in both sectors. ${ }^{7}$

In addition to the differences in the means of the observable characteristics discussed above, there are substantial differences in the allocation of characteristics across the earnings distribution (see Tables A1 to A4 of the Appendix) ${ }^{8}$. For example, carrying out managerial duties or being a manager is generally increasingly common for men across the earnings distribution. This is particularly noticeable amongst the highest three deciles of earners in the public sector.

Supporting evidence of the relative scarcity of senior women in high skilled, white-collar occupations has been recently established by the Equal Opportunity Commission (2005, page 1), who found that women in Britain make up just $8 \%$ of the senior judiciary, $8 \%$ of senior police officers, $10 \%$ of top business leaders and $9 \%$ of national newspaper editors. Similar results are found for lawyers in the U.S. with only some $6 \%$ of law firms having managing partners who are female (National Association of Women Lawyers, 2008; pages 2-7).

\footnotetext{
${ }^{7}$ The correlation coefficient between being a manager and having managerial duties is 0.47 .

${ }^{8}$ Tables A1 to A4 of the Appendix report descriptive statistics for each decile sub-sample of men and women in the private sector and the public sectors.
} 
Considering differences in education, in the public sector women are as likely to have a degree or another higher educational qualification as are men (Table 1). In the private sector, however, men are more likely to hold these higher education qualifications than women.

Furthermore, in contrast to all women, women working full-time are more likely to have observed characteristics that are typically associated with greater earnings potential, such as higher levels of education and more years of work experience. Full-time working women are less likely to have young children in the household and they are more likely to have positive attitudes to the acceptability of mothers working full-time.

\section{Estimation}

We use the quantile regression (QR) model of Koenker and Bassett (1978) to estimate earnings functions for males $(m)$ and females $(f)$ :

$w_{i m}=x_{i m}{ }^{\prime} \beta_{\theta m}+u_{\theta i m}$ with $\operatorname{Quant}_{\theta}\left(w_{i m} \mid x_{i m}\right)=x_{i m}{ }^{\prime} \beta_{\theta m} \quad i=(1, \ldots, \mathrm{n})$

$w_{i f}=x_{i f} \beta_{\theta f}+u_{\theta i f}$ with $\operatorname{Quant}_{\theta}\left(w_{i f} \mid x_{i f}\right)=x_{i f} \beta_{\theta f} \quad i=(1, \ldots, \mathrm{n})$

where $w_{i}$ is the natural $\log$ of the hourly earnings of individual $i ; x_{i}$ is a $\mathrm{Kx} 1$ vector of regressors measuring a range of individual characteristics; and $u_{\theta i}$ is a residual term. The distribution of the residual term $u_{\theta i}$ is unspecified, but $u_{\theta i}$ satisfies Quant $_{\theta}\left(w_{i} \mid x_{i}\right)=0$ where Quant $_{\theta}\left(w_{i} \mid x_{i}\right)$ denotes the $\theta$ th conditional quantile of $w_{i}$ given $x_{i}$. It can be shown that the estimates $\hat{\beta}$, the quantile regression (QR) coefficients, are consistent estimates of the rates of return to observed characteristics at different quantiles in the conditional wage distribution (see, for example, Machado and Mata, 2005; page 447).

The widely referred to papers of Oaxaca (1973) and Blinder (1973) explain how decomposition analysis can be used to separate the portion of the differences in the mean wages (the gap) associated with males and females having different observed characteristics (the 'explained portion' or 'observables') from the portion of the gap associated with the returns to these characteristics differing across the genders (the ‘unexplained portion' or 'unobservables'). Machado and Mata (2005) generalise 
the Oaxaca-Blinder method to enable such a decomposition to take place at conditional quantile $\theta$ in the wage distribution.

The need to allow for sample selection when estimating an earnings function, such as selection into full-time work by women, is well documented by Heckman (1979). Heckman proposed a parametric estimator to correct for potential selection bias. Buchinsky (1998) proposes using a semiparimetric estimator for selection correction in the QR model and provides examples. Albrecht et al., (2007) employ the Buchinsky method and extend the Machado-Mata decomposition method to account for selection in the quantile regression framework.

We incorporate the Buchinsky selection correction approach when estimating $\beta(\theta)$ for women working full-time $(f f)$ :

$w_{i f f}=x_{i f f} \beta_{\theta f f}+h_{\theta}\left(z_{i f f} \gamma^{\prime} \gamma\right)+u_{\theta i f f}$ with Quant ${ }_{\theta}\left(w_{i f f} z_{i f f}=x_{i f f}\right)=x_{i f f} \beta_{\theta f}+h_{\theta}\left(z_{i f f} \gamma^{\prime}\right)$

where $z_{f f}$ is the set of variables that influence the probability that a woman works fulltime (including a selection of $x_{f}$ ) for individual $i$; and the term $h_{\theta}\left(z_{i f f} f^{\prime}\right)$ is analogous to the Mill's ratio in the Heckman procedure with parameters $\gamma$. (For identification, $z_{f f}$ also includes at least one continuous variable not included in $x_{f}$.) The selection effect can further be decomposed into the portion due to observables and the portion due to unobservables.

Table 2 provides results from standard probit and single index (Ichimura, 1993) estimation of the determinants of participating in full-time work by women (in columns 1 and 2, respectively) ${ }^{9}$ in the public sector (top panel) and the private sector (bottom panel). Women are found to be significantly more likely to be working fulltime if they have more years of work experience and higher education qualifications (O-Level and/or above), holding other covariates constant. The relationship between higher education and participation is particularly strong in the public sector. In contrast, being married and the presence of dependent children are both strongly negatively related to the probability of women participating in full-time employment. Women are significantly more likely to work full-time if they disagree with the attitudinal statement that the "family suffers if the mother works full-time”.

\footnotetext{
${ }^{9}$ The constant and the coefficient on the first continuous variable (years of work experience) are not identified in the single index model, they are normalised here by setting them equal to the corresponding values in the probit model, thereby making the results of the two models comparable.
} 
Figures 3a and 3b show the gender wage gap between full-time men and fulltime women after adjusting for self-selection in the public and private sectors, respectively. This is the difference between the distribution of men's full-time wages and the distribution of wages that women would earn if all women worked full-time. Compared with the raw gender earnings gap in Figures $2 \mathrm{a}$ and $2 \mathrm{~b}$, the selection adjusted gender earnings gap is substantially higher overall (especially in the private sector) and there is again evidence of a glass ceiling effects.

\subsection{Decomposing the Selection Effect for Women}

Following Albrecht et al., (2007), we decompose the selection effect into the portion due to observed differences between those women working full-time (in each sector) and all women (the so called 'explained' component, as shown in Figures 4a and 4b), and the portion due to unobserved differences (the 'unexplained' component as shown in Figures 5a and 5b).

In the public sector, the explained component of the selection effect can be seen to be statistically significant at around 10 lwp from the bottom of the wage distribution up to the $90^{\text {th }}$ quantile (Figure 4a). Interestingly, this gap tends to be greatest around the middle of the distribution. By contrast, the unexplained component of the selection effect is rarely significantly different from zero at any point in the distribution for full-time workers in the public sector (Figure 5a). These findings suggest that virtually the entire positive selection effect into the public sector is due to differences in observable characteristics associated with a higher earnings potential between those women who work full-time in this sector and all women.

In the private sector, the portion of the selection effect due to observed differences is not significantly different to zero in the lowest three deciles, but then it rises up to the $90^{\text {th }}$ quantile (Figure $4 \mathrm{~b}$ ). This implies that higher earning women in the private sector are increasingly more likely to have those observable characteristics associated with higher pay than are all women. There is also evidence of a positive selection effect due to 'unobservables' in the lowest two deciles (Figure 5b).

Ignoring the positive selection into the public and private sectors by full-time working women could be expected to lead to incorrect estimates of the true extent of the gender earnings gaps. Allowance for selection is made accordingly in the estimation of the earnings functions for full-time working women below. 


\section{Earnings Function Results}

Quantile regressions for log hourly earnings are estimated separately for full-time men and women in the private sector (results are presented in panels 1 and 2 of Table 3, respectively); and full-time men and full-time women in the public sector (panels 1 and 2 of Table 4, respectively). The quantile regression results for the full-time women include Buchinsky's selection correction. ${ }^{10}$ As discussed above, the basic human capital explanatory variables (education, experience and experience squared) are included; these are augmented with additional explanatory variables (being married, occupation, managerial duties, firm size, and region).

The basic human capital variables are typically found to be significant across all deciles of the wage distribution and to have the expected relationship with earnings for men in the private sector (Table 3, panel 1). For example, the total returns to work experience peak at 13 years and begin to become negative (starting with the lowest earnings deciles) at 27 years. There are also substantial gains associated with higher education qualifications, being married, or working in a large workplace. These relationships are similar across the distribution. Having a skilled occupation (especially managerial, professional or associate professional) and carrying out managerial duties are associated with increasing positive returns for higher income earners. The results are similar although less precisely estimated for the smaller sample of full-time women working in the private sector (with the exception of being married where there is actually some evidence of a negative relationship with wages especially at the lower earnings levels). The increasing returns associated with having a more skilled occupation are clear amongst higher earning women in the private sector (the returns to being a Manager in the top decile of the earnings distribution are more than double that of a Manager in the second lowest decile; Professionals can expect almost half as much again; and Associate Professionals more than an additional quarter).

Results for men in the public sector (see Table 4) are broadly similar to those found for men in the private sector: the basic human capital variables are again found to be generally significant and to have the expected relationship with earnings. The total impact of work experience for men peaks later (at 17 years) and becomes

\footnotetext{
${ }^{10}$ For full-time women in the public sector, the function $h_{\theta}\left(\mathrm{z}_{f}^{\prime} f\right)$ is a cubic function of the filtered single index selection probability (column 2 of Table 2). The analogous selection corrected results for fulltime women in the private sector incorporate the single index selection probability (Table 2).
} 
negative from 26 years for decile 5. The increasing returns associated with the high skilled, white-collar occupations again rise substantially across the earnings distribution for men. By contrast, the greatest returns for females from having a high skilled, white-collar occupation are found amongst the lowest two deciles of the income distribution (where the returns associated with being a Manager, Professional, or Associate Professional are more than double the returns found in the highest decile). The returns from managerial duties also decrease amongst higher earners for females in the public sector. This is not the case for men; the positive impact on earnings related to these duties is some $50 \%$ larger for men than women in the highest decile of earners in the public sector.

\section{Decomposing the Gender Wage Gap}

Figure 6a shows the counterfactual distribution of the gap (in the public sector) between men's wages and the wages that women would earn if women retain their own distribution of characteristics but are rewarded for them like men. ${ }^{11}$ This gap is not statistically significant from zero throughout the distribution (Figure 6a), suggesting that the gender gap in the public sector would essentially disappear if women's returns to their observed characteristics were equal to men's. In the private sector there is some evidence of a small but statistically significant gap amongst the top earners - above the $80^{\text {th }}$ quantile (Figure 6b) - implying a relative under endowment of observable characteristics associated with higher pay for the highest earning women in this sector.

Figures $7 \mathrm{a}$ and $\mathrm{b}$ plot the gap between the full-time male log wage distribution and the counterfactual distribution of wages that full-time women would earn if they had male characteristics but full-time women's (selection-adjusted) returns to these characteristics in the public and private sector, respectively. The gender earnings gap is positive and significant across the entire distribution in both sectors, and it is substantially larger in the private sector. Interestingly, the gap in the public sector is lower between the $40^{\text {th }}$ and the $70^{\text {th }}$ quantiles. The estimated gap is strongly increasing from the $80^{\text {th }}$ quantile, again suggesting the presence of a glass ceiling for full-time women in the public sector. In the private sector the gap rises strongly until approximately the $80^{\text {th }}$ quantile after which it falls, nevertheless, the gap is still

\footnotetext{
${ }^{11}$ The difference between this counterfactual and the gap in the raw data (Figure 2a) is analogous to the explained component of the traditional Oaxaca decomposition.
} 
considerably larger at higher quantiles than at the lower quantiles of the distribution. Furthermore, the gap amongst the highest income earners is larger in the private sector than in the public.

From April 2007, public authorities in the UK are required to implement the Gender Equality Duty (GED) according to the Single Equality Act 2006. The GED places a responsibility to take due regard to eliminate unlawful sex discrimination and to promote equality of opportunity between men and women. Our findings of substantial unexplained differences in returns to observable characteristics for fulltime working men and women in the public sector indicate that gender based discrimination may be occurring. Furthermore, the scarcity of women working as managers or carrying out managerial duties amongst the highest income earners may indicate that women are not offered the opportunity to take on roles that are typically associated with the higher grades of public sector employment. ${ }^{12}$ We might expect application of the GED may erode some of these differences in the future.

Our findings for the private sector also suggest that there is a scarcity of high earning females who are managers, professionals or carrying out managerial duties in the private sector. This may also be indicative of a lack of opportunity for full-time working women in this sector. The GED is not directly applicable to the private sector under the Single Equality Act 2006; it is not clear what (if any) impact it will have on this sector in the short-run.

\section{Conclusion}

We find the mean log gender wage gap between full-time workers in Britain is 16 log wage points (25 log wage points in the private sector and 14 in the public sector). Taking the log wage gap at each quantile of the male and female distributions reveals a more detailed picture. The unadjusted gender wage gap in both sectors shows a tendency to increase across the distribution with a glass ceiling effect indicated in both sectors.

Given the large proportion of female workers in Britain who work part-time, the possibility of sample selection into full-time work for women is addressed and found to be to be positive, significant and substantially related to differences in observed characteristics in both sectors. If all women worked full-time, the gender

\footnotetext{
${ }^{12}$ Sometimes referred to as the 'Senior Grades'; many of which have their earnings reviewed by the Senior Salaries Review Body (of the Office of Manpower Economics).
} 
wage gap would be larger than that which is observed amongst existing full-time workers.

After allowing for selection into full-time employment by British women, significant and sizeable gender earnings gaps remain in both sectors (as do the glass ceiling effects). In aggregate, our decomposition results suggest that the gender earnings gap would all but disappear in the public sector if women received the same returns to their characteristics as men do. In the private sector the gap would disappear for all but the top earners, for whom the gap would become considerably smaller than currently observed.

A strong relationship between high skilled white-collar occupations and carrying out managerial duties with glass ceiling effects is found in this paper. In the private sector, there are comparatively few women in these high skilled, white-collar occupations at the top deciles of the earnings distribution. In the public sector, there is also a scarcity of women who are managers. In addition, women who carry out managerial duties are rare and relatively underpaid in both sectors. A full evaluation of the success of the Equal Opportunity law in Britain (and, in particular, the General Equality Duty) should address differences across the earnings distribution such as those found here.

\section{References}

Albrecht, J. Bjorkland, A. and Vroman, S. (2003). "Is there a glass ceiling over Sweden?” Journal of Labor Economics 21; 145-177.

Albrecht, J. van Vuuren, A. and Vroman, S. (2007). "Decomposing the gender wage gap in the Netherlands with sample selection adjustments." IZA Discussion Paper No. 1400.

Altonji, J.G. and Blank, R. (1999). 'Race and gender in the labor market' in Ashenfelter, O. and Card, D. (eds) Handbook of Labor Economics. Elsevier Science B.V, Amsterdam.

Arulampalam, W. Booth, A.L. and Bryan, M. (2007). "Is there a glass ceiling over Europe: An exploration of asymmetries in the gender pay gap across the wage distributions.” Industrial and Labor Relations Review 60(2); 163-186.

Baron, J.D. and Cobb-Clark, D.A. (2008). "Occupational segregation and the gender wage-gap in private and public sector employment: A distributional analysis.” IZA Discussion Paper No. 3562.

Becker, G.S. (1962). “Investment in human capital: A theoretical analysis', Journal of Political Economy 70; 9-49.

Becker, G.S. (1964). Human Capital: A Theoretical and Empirical Analysis, with Special Reference to Education (The University of Chicago Press, Chicago).

Blau, F.D. and Kahn, L.M. (2003). understanding international differences in the gender pay gap. Journal of Labor Economics 21; 106-144. 
Blinder, A. (1973). "Wage discrimination: reduced form and structural estimates." Journal of Human Resources 8; 436-55.

Blundell, R. Gosling, A. Ichimura, H. and Meghir, C. (2007). "Changes in the distribution of male and female wages accounting for employment composition using bounds.” Econometrica 75(2); 323-363

Buchinsky, M. (1998). "The dynamics of change in the female wage distribution in the USA: A quantile regression approach.” Journal of Applied Econometrics $13 ; 1-30$.

Burgess, S and Ratto, M (2003), "The role of incentives in the public sector: Issues and evidence”, Oxford Review of Economic Policy 19(2); 285-300.

Chatterji, M. Smith, P.N. and Mumford, K.A. (2008). "The public-private sector gender wage differential: Evidence from matched employee-workplace data”. IZA Discussion Paper No 3158.

Connolly, S. and Gregory, M. (2008). 'Moving down? Women's part-time work and occupational change in Britain 1991-2001.' Economic Journal 118, F52-76

de la Rica, S. Dolado, J.J. and Llorens, V. (2008). " Ceilings and floors: Gender wage gaps by education in Spain.” Journal of Population Economics 21(3); 751-776.

Dickens, L. (2007). The Road is long: Thirty years of equality legislation in Britain. British Journal of Industrial Relations 45(3): 463-494.

Disney, R. and Gosling, A. (2003). "A new method for estimating public sector pay premia: Evidence from Britain in the 1990's," CEPR Discussion Papers 3787.

Equal Opportunity Commission (2005). Sex and Power: Who Runs Britain?

Gregory, R. and Borland, J. (1999). "Recent developments in public sector labor markets” published in Ashenfelter, O. and Card, D. editors Handbook of Labor Economics, Volume 3C. (North Holland, Amsterdam).

Halpin, B. (2006). "BHPS Work-life history files, version 2," mimeo, ISER, University of Essex, Colchester. Available online at UKDA (documentation for study 3954)

Heckman, J. (1979). "Sample selection bias as a specification error”. Econometrica 47; $153-161$.

Ichimura, H. (1993) "Semiparametric least squares (SLS) and weighted SLS estimation of single index models". Journal of Econometrics 58; 71-120.

Koenker, R. and Bassett, G. (1978). “Regression quantiles.” Econometrica 46; 33-50.

Machado, J.A. and Mata, J. (2005). "Counterfactual decomposition of changes in wage distributions using quantile regression.” Journal of Applied Econometrics 20; 445-465.

Manning, A. and Petrongolo, B. (2008). 'The part-time pay penalty for women in Britain.' Economic Journal 118, F28-51.

McRae, S. (2008). "Working full-time after motherhood" in Scott, J., Dex, S. and Joshi, H. (eds). Women and Employment: Changing Lives and New Challenges. Cheltenham: Edward Elgar.

Melly, B. (2006). "Estimation of counterfactual distributions using quantile regression” Review of Labor Economics 68; 543-572.

Mincer, J. (1958). "Investment in human capital and personal income distribution.” Journal of Political Economy 66(4); 281-302;

Mumford, K. and Smith, P.N. (2007). "The gender earnings gap in Britain: Including the workplace.” Manchester School, 75, 653-72.

Mumford, K.A. and Smith, P.N. (2009). "What determines the part-time and gender earnings gaps in Britain: Evidence from the workplace.” Forthcoming, Oxford Economic Papers. 
National Association of Women Lawyers (2008). Report on the Third Annual Survey.

Nicodemo, C. (2009). "Gender gap and quantile regression in European families." IZA Discussion Paper No. 3978.

Oaxaca, R.L. (1973). "Male female wage differentials in urban labor markets." International Economic Review 14(3); 693-709.

Pfiefer, C. (2008). "Risk aversion and sorting into public sector employment." IZA Discussion Paper No. 3503.

Polachek, S. (2006). "How the human capital model explains why the gender wage gap narrowed.” Published in: F. Blau, M. Brinton, and D. Grusky, (eds.) The Declining Significance of Gender? ( New York: Russell Sage Foundation).

Regan, T.L. and Oaxaca, R.L. (2008). 'Work experience as a source of specification error in earnings models: Implications for gender wage decompositions.' Journal of Population Economics, forthcoming.

Weichselbaumer, D., and Winter-Ebmer, R. (2005). 'A meta-analysis of the international gender wage gap.’ Journal of Economic Surveys 9, 479-511.

Wilborn, S.L. 1991. "Economic and legal perspectives on women's wages in six countries: An overview.” in S.L. Wilborn, ed. Women's Wages: Stability and Change in Six Industrial Countries. Greenwich, CN: JAI Press. 
Table 1

Variable Definitions and Means (BHPS Wave 15)

\begin{tabular}{|c|c|c|c|c|c|c|c|c|}
\hline \multirow[b]{2}{*}{ Definitions } & \multirow[b]{2}{*}{$\begin{array}{l}\text { Full- } \\
\text { time }\end{array}$} & & & \multirow[b]{2}{*}{$\begin{array}{c}\text { Non } \\
\text { working }\end{array}$} & \multicolumn{2}{|c|}{ Public Sector } & \multicolumn{2}{|c|}{ Private Sector } \\
\hline & & $\begin{array}{c}\text { Full- } \\
\text { time } \\
\text { women } \\
(3)\end{array}$ & $\begin{array}{c}\text { Part- } \\
\text { time } \\
\text { women } \\
(4)\end{array}$ & & $\begin{array}{c}\text { Full- } \\
\text { time } \\
\text { men, } \\
(6)\end{array}$ & $\begin{array}{c}\text { Full- } \\
\text { time } \\
\text { women } \\
(7)\end{array}$ & $\begin{array}{l}\text { Full- } \\
\text { time } \\
\text { men } \\
(8)\end{array}$ & $\begin{array}{c}\text { Full- } \\
\text { time } \\
\text { women } \\
(9)\end{array}$ \\
\hline Wage & 13.50 & 11.48 & 8.88 & - & 14.30 & 12.67 & 13.28 & 10.33 \\
\hline Log wage & 2.47 & 2.31 & 2.04 & - & 2.56 & 2.42 & 2.45 & 2.20 \\
\hline Work experience (years) & 13.05 & 11.61 & 10.60 & 3.86 & 13.33 & 11.73 & 12.87 & 11.50 \\
\hline Age & 39.97 & 39.94 & 40.83 & 40.48 & 40.98 & 40.83 & 39.69 & 39.07 \\
\hline \multicolumn{9}{|l|}{ Highest level of education } \\
\hline Degree & 0.23 & 0.29 & 0.16 & 0.15 & 0.36 & 0.42 & 0.19 & 0.16 \\
\hline Other higher & 0.42 & 0.36 & 0.37 & 0.23 & 0.41 & 0.35 & 0.42 & 0.37 \\
\hline A-levels & 0.10 & 0.10 & 0.11 & 0.13 & 0.08 & 0.07 & 0.11 & 0.13 \\
\hline O-levels & 0.15 & 0.15 & 0.19 & 0.21 & 0.09 & 0.12 & 0.16 & 0.19 \\
\hline Other & 0.05 & 0.05 & 0.07 & 0.11 & 0.03 & 0.04 & 0.06 & 0.07 \\
\hline None & 0.05 & 0.04 & 0.08 & 0.18 & 0.02 & 0.01 & 0.06 & 0.07 \\
\hline Married & 0.63 & 0.52 & 0.76 & 0.62 & 0.36 & 0.42 & 0.19 & 0.16 \\
\hline $\begin{array}{l}\text { Disagree that family suffers if } \\
\text { mother works full-time }\end{array}$ & 0.40 & 0.54 & 0.33 & 0.30 & 0.42 & 0.53 & 0.39 & 0.55 \\
\hline Child(ren) present & 0.45 & 0.33 & 0.70 & 0.63 & 0.45 & 0.35 & 0.45 & 0.30 \\
\hline \multicolumn{9}{|c|}{ Age of youngest child in household } \\
\hline 5 years or younger & 0.51 & 0.31 & 0.45 & 0.58 & 0.47 & 0.29 & 0.52 & 0.34 \\
\hline $6-11$ years & 0.31 & 0.37 & 0.35 & 0.29 & 0.38 & 0.42 & 0.29 & 0.31 \\
\hline $12-15$ years & 0.18 & 0.32 & 0.20 & 0.12 & 0.15 & 0.29 & 0.19 & 0.34 \\
\hline \multicolumn{9}{|l|}{ Region } \\
\hline South & 0.29 & 0.27 & 0.30 & 0.30 & 0.28 & 0.24 & 0.29 & 0.30 \\
\hline London & 0.08 & 0.10 & 0.07 & 0.09 & 0.10 & 0.11 & 0.08 & 0.09 \\
\hline East Midlands & 0.23 & 0.21 & 0.24 & 0.24 & 0.16 & 0.19 & 0.26 & 0.22 \\
\hline North & 0.25 & 0.26 & 0.27 & 0.26 & 0.28 & 0.27 & 0.24 & 0.26 \\
\hline Wales & 0.05 & 0.05 & 0.05 & 0.03 & 0.06 & 0.06 & 0.04 & 0.03 \\
\hline Scotland & 0.09 & 0.11 & 0.08 & 0.08 & 0.12 & 0.13 & 0.09 & 0.10 \\
\hline Managerial duties & 0.47 & 0.45 & 0.16 & - & 0.49 & 0.45 & 0.46 & 0.45 \\
\hline \multicolumn{9}{|l|}{ Size of firm } \\
\hline Less than 25 & 0.27 & 0.29 & 0.42 & - & 0.18 & 0.23 & 0.29 & 0.36 \\
\hline $25-199$ & 0.38 & 0.41 & 0.33 & - & 0.39 & 0.46 & 0.37 & 0.36 \\
\hline 200 or over & 0.36 & 0.30 & 0.25 & - & 0.43 & 0.32 & 0.33 & 0.28 \\
\hline Private sector & 0.78 & 0.51 & 0.53 & - & 0 & 0 & 1 & 1 \\
\hline \multicolumn{9}{|l|}{ Occupational category } \\
\hline Managers & 0.21 & 0.15 & 0.05 & - & 0.12 & 0.08 & 0.24 & 0.21 \\
\hline Professionals & 0.14 & 0.18 & 0.09 & - & 0.24 & 0.29 & 0.11 & 0.07 \\
\hline \multicolumn{9}{|l|}{ Technicians and Associate } \\
\hline Professionals & 0.16 & 0.19 & 0.10 & & 0.29 & 0.24 & 0.12 & 0.13 \\
\hline Admin/Secretarial & 0.05 & 0.23 & 0.23 & - & 0.11 & 0.23 & 0.03 & 0.23 \\
\hline Skilled Trades & 0.18 & 0.02 & 0.02 & - & 0.08 & 0.01 & 0.20 & 0.04 \\
\hline $\begin{array}{l}\text { Personal Services } \\
\text { Sales and Customer }\end{array}$ & 0.01 & 0.10 & 0.18 & - & 0.04 & 0.13 & 0.01 & 0.08 \\
\hline Services & 0.02 & 0.06 & 0.19 & & 0.00 & 0.00 & 0.03 & 0.12 \\
\hline Operatives & 0.14 & 0.03 & 0.01 & - & 0.03 & 0.00 & 0.17 & 0.06 \\
\hline Elementary & 0.09 & 0.04 & 0.14 & - & 0.08 & 0.03 & 0.09 & 0.05 \\
\hline Unweighted No. observations & 1747 & 1283 & 665 & 528 & 412 & 659 & 1335 & 624 \\
\hline
\end{tabular}

Source: British Household Panel Survey, Wave 15. Cross-sectional weights used. 
Figure 1. Kernel Density Earnings Estimates for Men and Women Working Full-Time in Britain, by Sector.

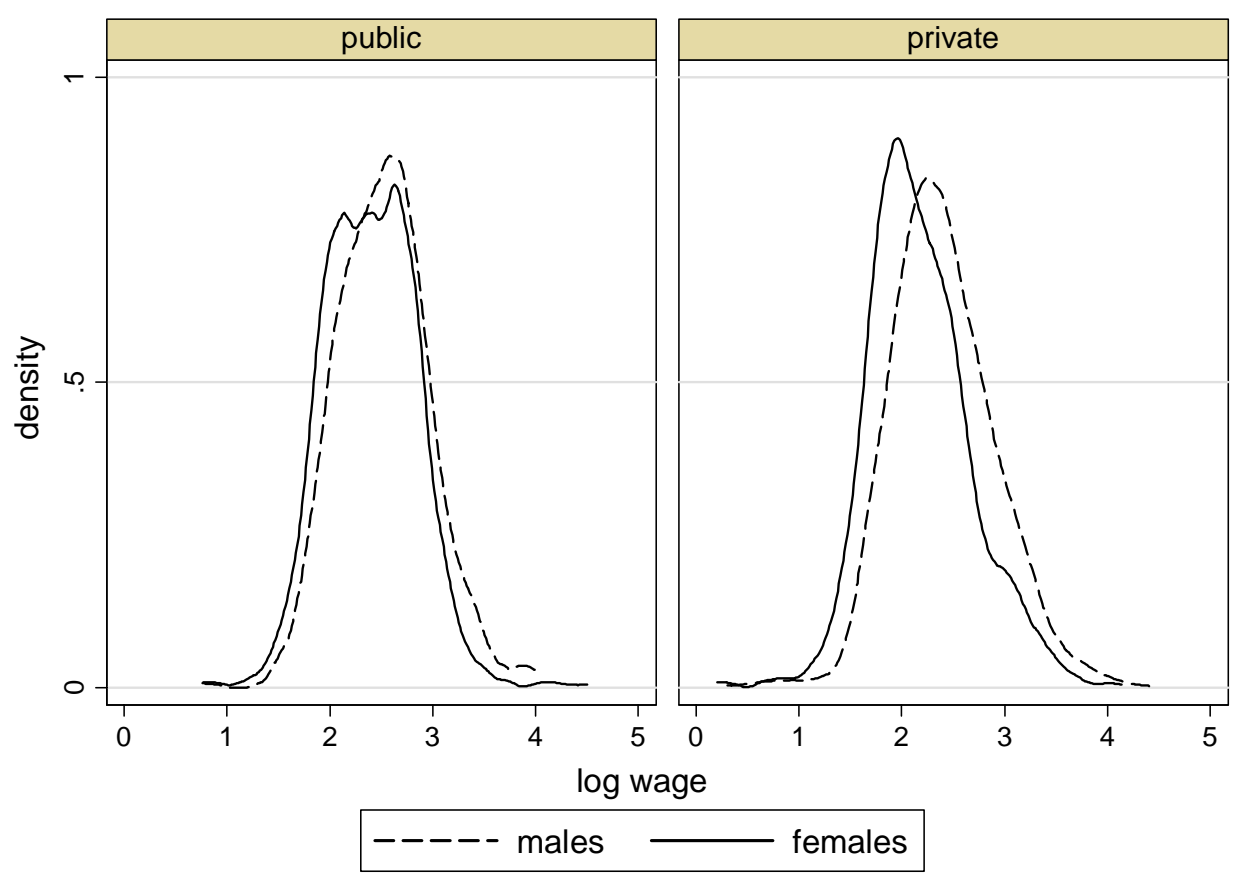


Figure 2a. The Unadjusted Gender Log Wage Gap in the Public Sector

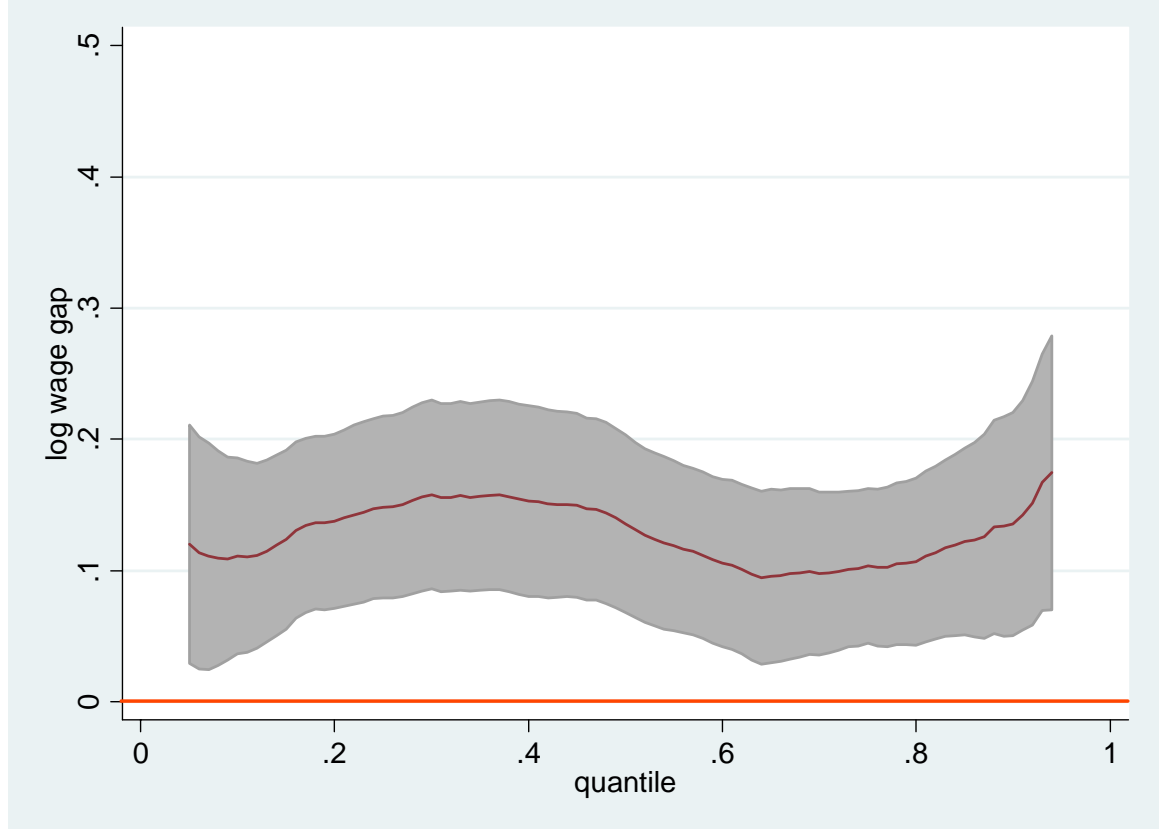

Figure 2b. The Unadjusted Gender Log Wage Gap in the Private Sector

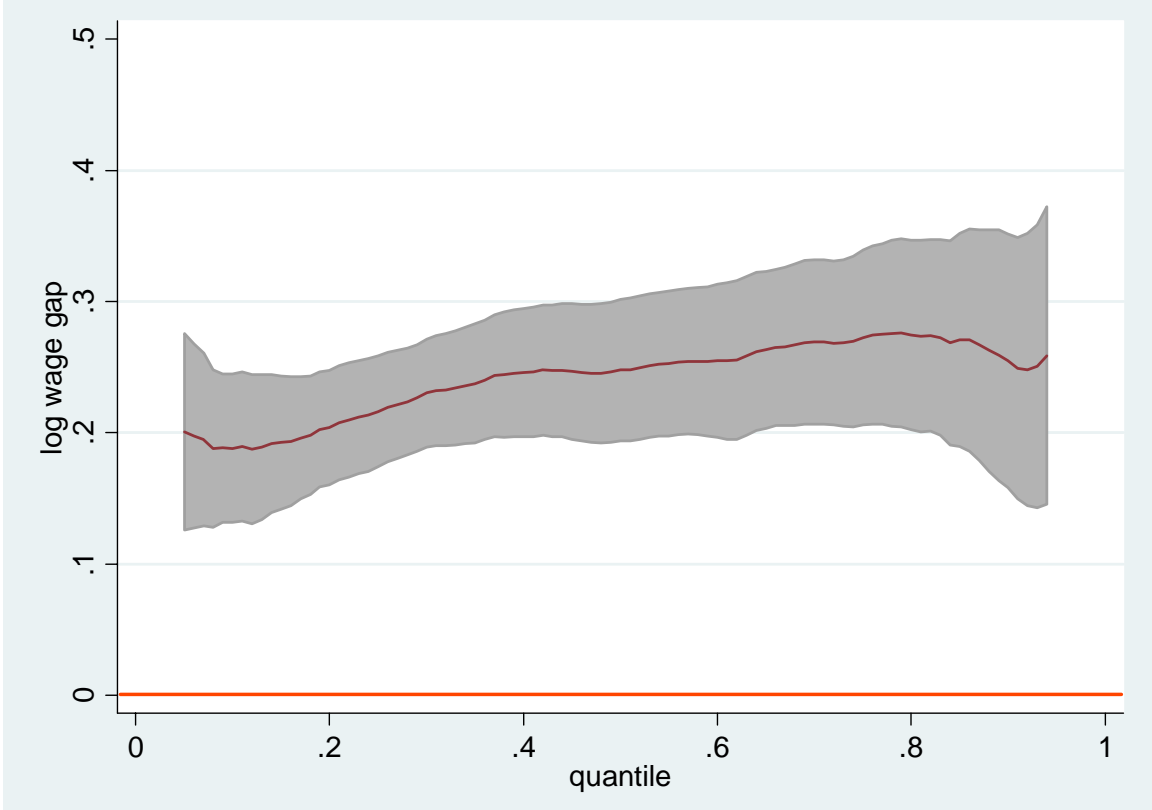


Table 2.

Estimates of the Incidence of Full-Time Work amongst Women.

\begin{tabular}{|c|c|c|c|c|}
\hline & \multicolumn{4}{|c|}{ Public sector } \\
\hline & \multicolumn{2}{|c|}{ Probit (1) } & \multicolumn{2}{|c|}{ Single Index (2) } \\
\hline & $\mathrm{B}$ & SE & $\mathrm{B}$ & SE \\
\hline Constant & -0.47 & 0.30 & -0.47 & - \\
\hline Work experience (years) & $0.20 * \star \star$ & 0.02 & 0.20 & - \\
\hline Work experience squared (x 100) & 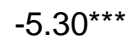 & 0.00 & $-2.65^{\star \star \star}$ & 0.00 \\
\hline Age & $-0.03^{\star * *}$ & 0.01 & $-0.02^{\star * *}$ & 0.00 \\
\hline Married & $-0.24^{\star \star}$ & 0.08 & $-0.12^{\star \star \star}$ & 0.02 \\
\hline Positive working mother attitude. & $0.36^{\star \star}$ & 0.11 & $0.31^{\star \star \star}$ & 0.03 \\
\hline Child(ren) present & $-1.06^{\star * *}$ & 0.11 & $-0.53^{\star \star \star}$ & 0.05 \\
\hline $\begin{array}{l}\text { Interaction between positive working } \\
\text { mother attitude and presence of children } \\
\text { Highest level of education (ref: none) }\end{array}$ & 0.25 & 0.16 & $0.12^{*}$ & 0.05 \\
\hline Degree & $1.37^{\star \star \star}$ & 0.19 & $0.69 * * *$ & 0.09 \\
\hline Other higher & $1.00^{\star * \star}$ & 0.19 & $0.50 * \star \star$ & 0.09 \\
\hline A-levels & $0.74^{\star \star \star}$ & 0.21 & $0.26^{\star}$ & 0.10 \\
\hline O-levels & $0.59 * *$ & 0.20 & $0.29 * *$ & 0.10 \\
\hline Other & 0.47 & 0.25 & $0.26^{\star \star}$ & 0.10 \\
\hline \multirow[t]{2}{*}{ Number of observations } & 1509 & 1509 & 1509 & 1509 \\
\hline & \multicolumn{4}{|c|}{ Private sector } \\
\hline
\end{tabular}

\begin{tabular}{|c|c|c|c|c|}
\hline & \multicolumn{2}{|c|}{ Probit (1) } & \multicolumn{2}{|c|}{ Single Index (2) } \\
\hline & $\mathrm{B}$ & SE & $\mathrm{B}$ & SE \\
\hline Constant & 0.11 & 0.27 & 0.11 & - \\
\hline Work experience (years) & $0.21^{\star \star *}$ & 0.02 & 0.21 & - \\
\hline Work experience squared (x 100) & $-5.69 * \star \star$ & 0.00 & $-1.43^{\star \star *}$ & 0.00 \\
\hline Age & $-0.03^{* * *}$ & 0.01 & $-0.01 * * *$ & 0.00 \\
\hline Married & $-0.30 * * *$ & 0.08 & $-0.07 * \star$ & 0.03 \\
\hline Positive working mother attitude. & $0.32^{\star *}$ & 0.11 & $0.09 * *$ & 0.03 \\
\hline Child(ren) present & $-0.97^{* * *}$ & 0.11 & $-0.26^{\star * *}$ & 0.04 \\
\hline $\begin{array}{l}\text { Interaction between positive working } \\
\text { mother attitude and presence of children } \\
\text { Highest level of education (ref: none) }\end{array}$ & 0.12 & 0.15 & 0.02 & 0.05 \\
\hline Degree & $0.56^{\star \star *}$ & 0.16 & $0.14^{*}$ & 0.06 \\
\hline Other higher & $0.36^{\star}$ & 0.14 & $0.13^{*}$ & 0.05 \\
\hline A-levels & $0.36^{\star}$ & 0.16 & $0.12^{*}$ & 0.06 \\
\hline O-levels & 0.23 & 0.15 & 0.04 & 0.05 \\
\hline Other & 0.09 & 0.18 & 0.02 & 0.06 \\
\hline Number of observations & 1495 & 1495 & 1495 & 1495 \\
\hline
\end{tabular}


Figure 3a. Gender Log Wage Gap between Full-Time Men's Wages and the Wages that Would be Observed if all Women Worked Full-Time (Public Sector)

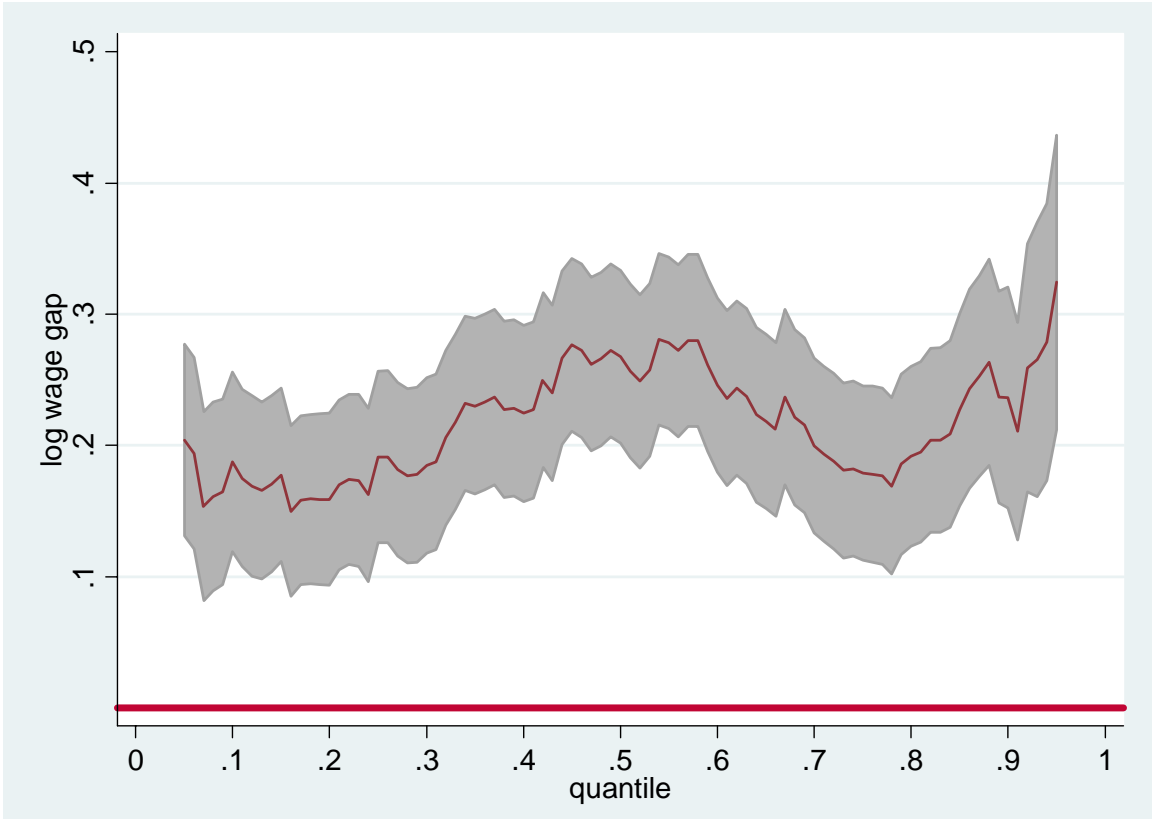

Figure 3b. Gender Log Wage Gap between Full-Time Men's Wages and the Wages that Would be Observed if all Women Worked Full-Time (Private Sector)

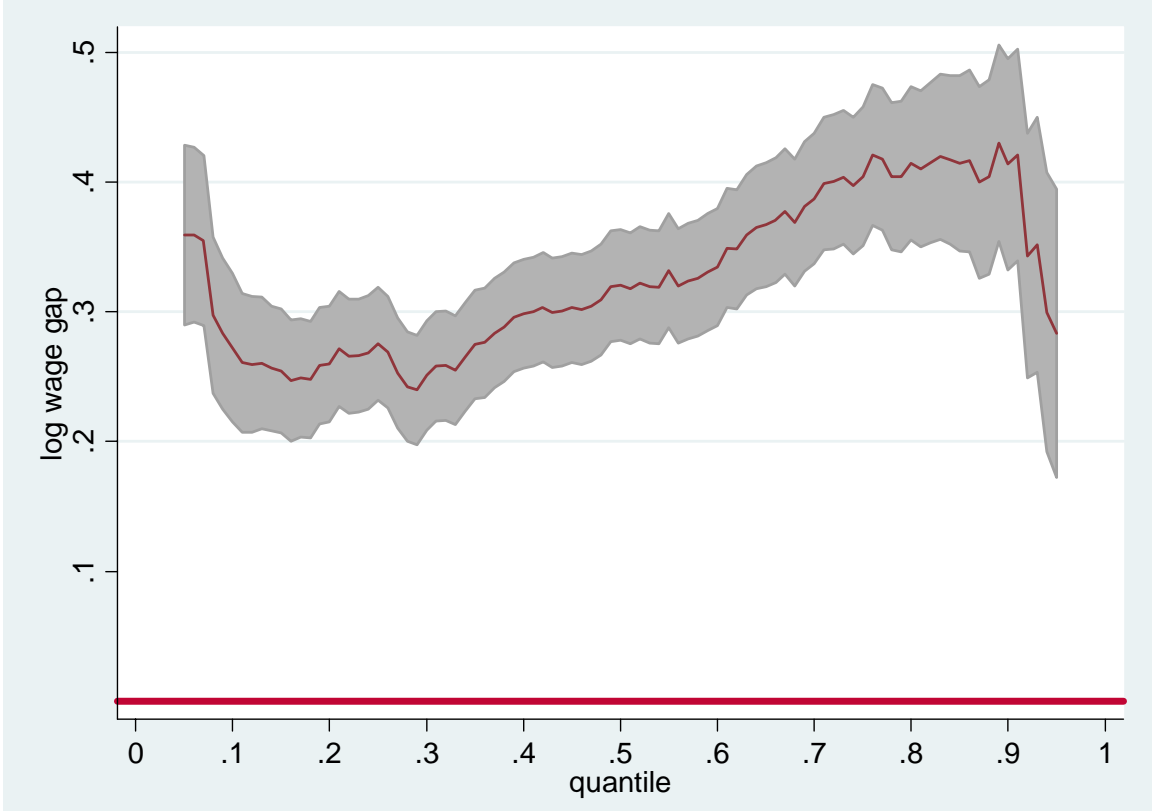


Figure 4a. Sample Selection Based on Observed Characteristics in the Public Sector.

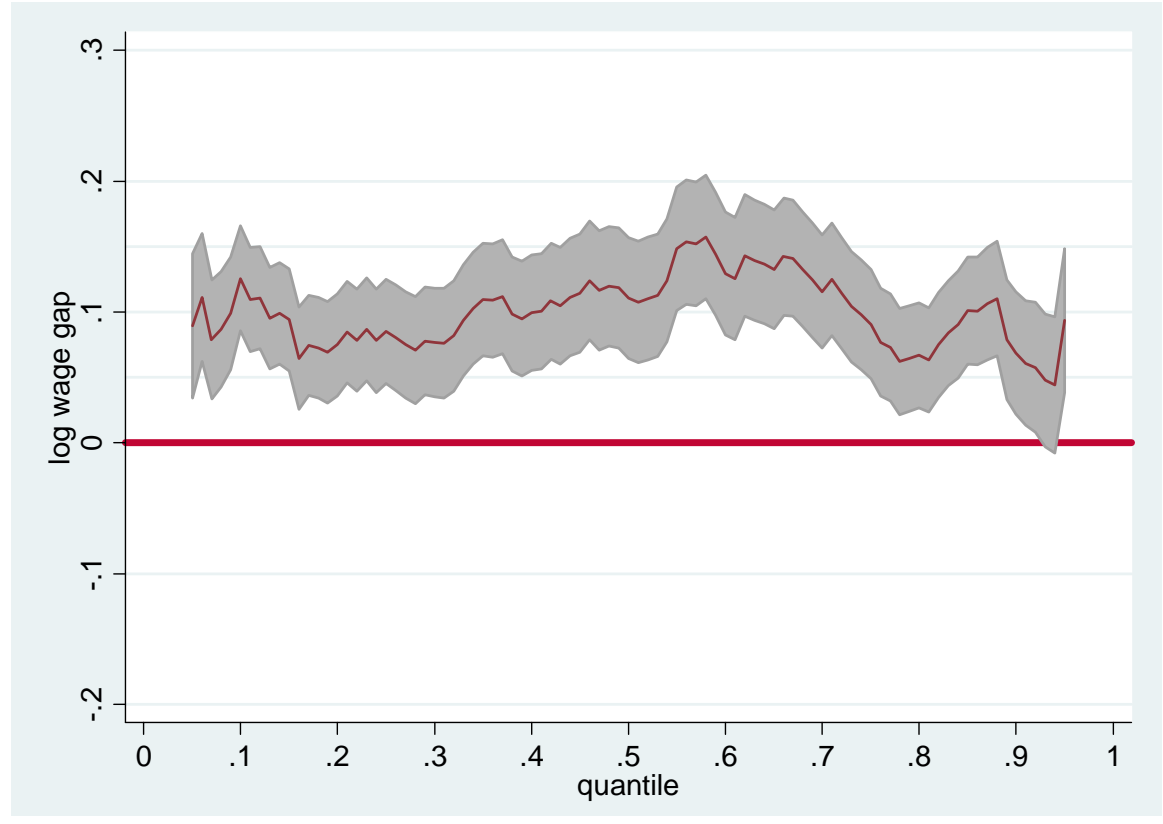

Figure 4b. Sample Selection Based on Observed Characteristics in the Private Sector.

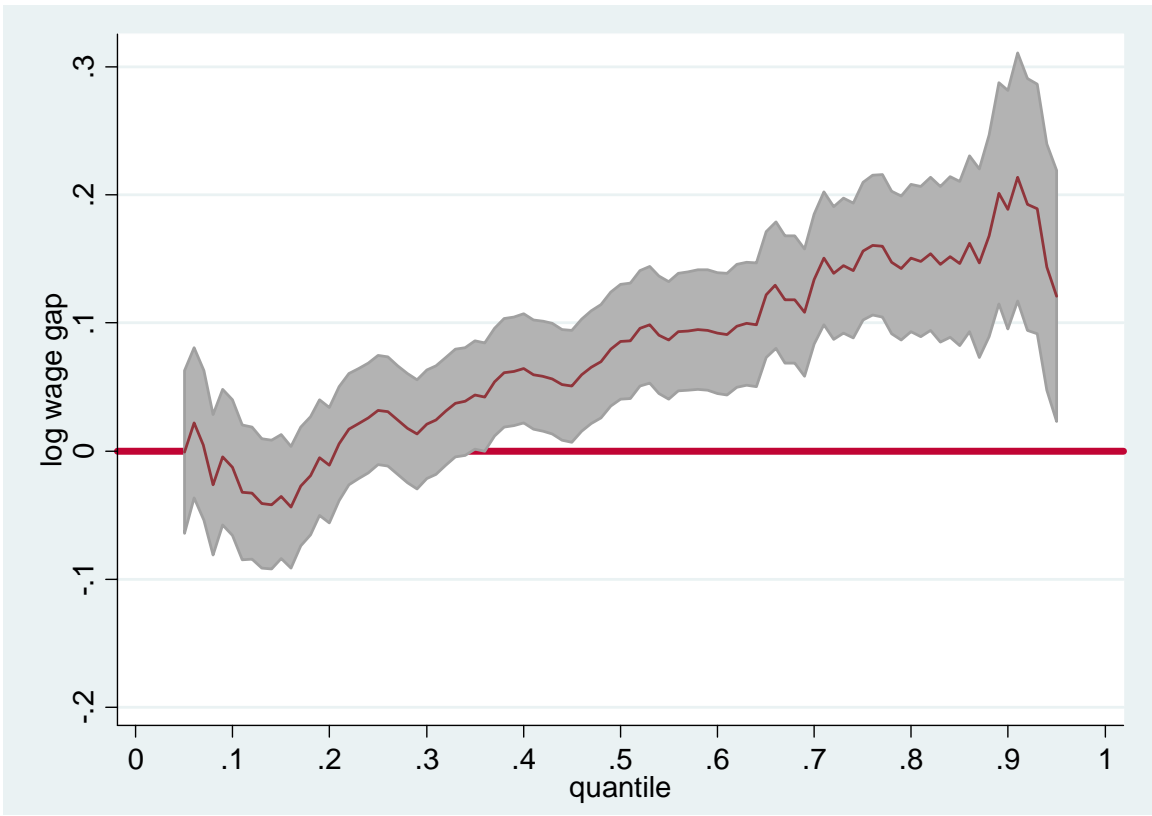


Figure 5a. Sample Selection Based on Unobserved Characteristics in the Public Sector.

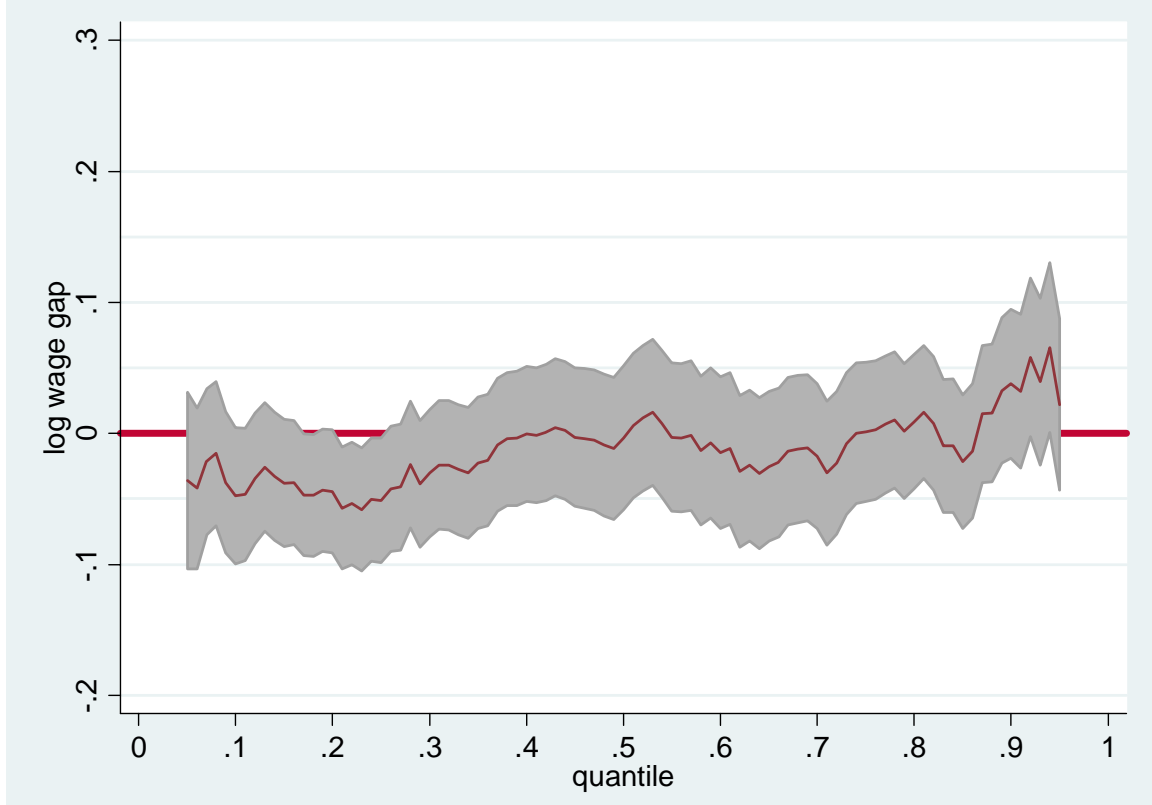

Figure 5b. Sample Selection Based on Unobserved Characteristics in the Private Sector.

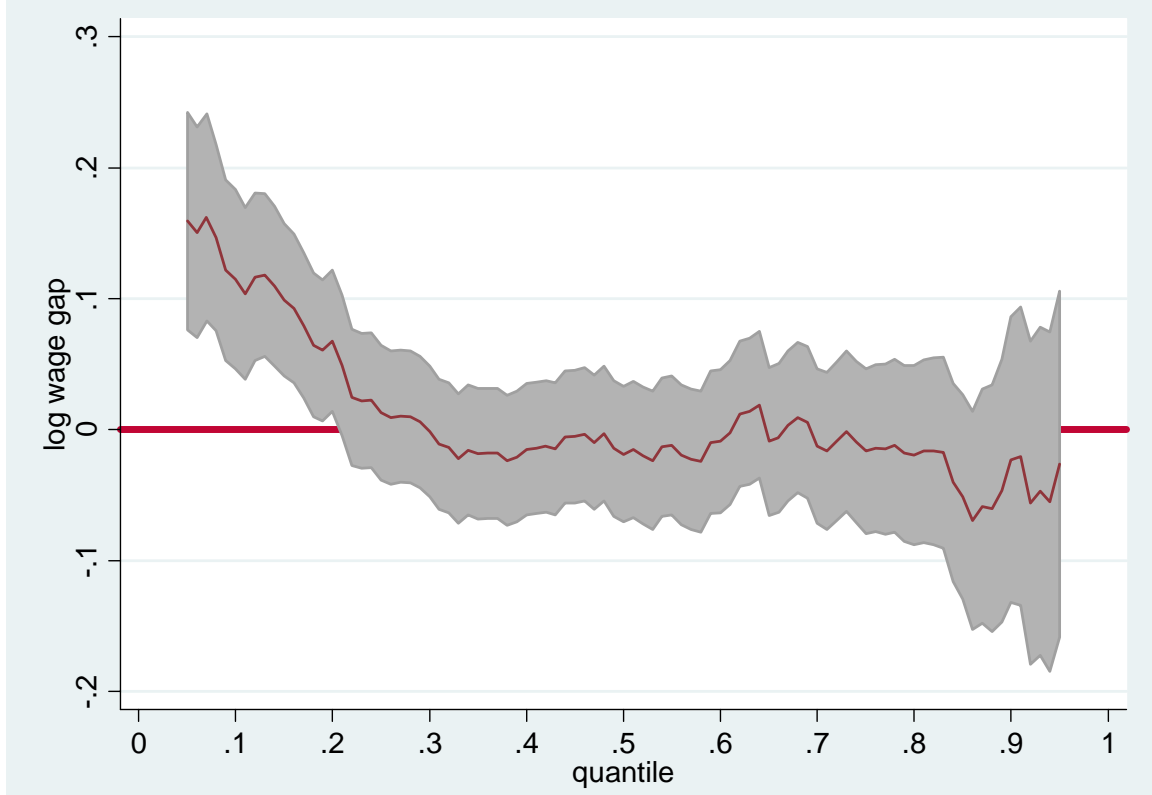


Table 3.

Quantile Earnings Regressions for Men and Women in the Private Sector.

\begin{tabular}{|c|c|c|c|c|c|c|c|c|c|}
\hline \multirow[t]{2}{*}{ Panel (1) } & \multicolumn{9}{|c|}{ Men in the Private sector } \\
\hline & $10 \%$ & $20 \%$ & $30 \%$ & $40 \%$ & $50 \%$ & $60 \%$ & $70 \%$ & $80 \%$ & $90 \%$ \\
\hline Constant & $1.30^{\star \star \star}$ & $1.47^{\star \star \star}$ & $1.55^{\star \star \star}$ & $1.57^{\star \star \star}$ & $1.70^{\star \star \star}$ & $1.75^{\star \star \star}$ & $1.88^{\star \star \star}$ & $1.95^{\star \star \star}$ & $2.03^{\star \star \star}$ \\
\hline Work experience (years) & $0.04^{\star \star *}$ & $0.04^{\star \star \star}$ & $0.04^{* * *}$ & $0.04^{\star \star \star}$ & $0.04^{\star \star \star}$ & $0.04^{* * *}$ & $0.04^{\star \star \star}$ & $0.05^{\star \star \star}$ & $0.06^{\star \star *}$ \\
\hline Work exp squared (x 1000) & $-0.92^{\star \star *}$ & $-1.01^{\star * *}$ & $-1.04^{\star * *}$ & $-1.14^{\star * *}$ & $-1.15^{\star * *}$ & $-1.16^{\star \star *}$ & $-1.19^{* * *}$ & $-1.54^{\star * *}$ & $-1.89^{\star * *}$ \\
\hline \multicolumn{10}{|c|}{ Highest level of education (ref: none) } \\
\hline Degree & $0.45^{\star * *}$ & $0.41^{\star \star \star}$ & $0.35^{\star \star \star}$ & $0.43^{\star * \star}$ & $0.41^{\star * \star}$ & $0.44^{\star \star *}$ & $0.46^{\star \star *}$ & $0.37^{\star * *}$ & $0.40^{\star \star *}$ \\
\hline Other higher & $0.23^{\star \star \star}$ & $0.20^{\star \star \star}$ & $0.15^{\star \star \star}$ & $0.21^{\star \star *}$ & $0.21^{\star * *}$ & $0.23^{\star \star *}$ & $0.20^{\star \star \star}$ & $0.15^{\star \star}$ & 0.08 \\
\hline A-levels & $0.22^{\star \star *}$ & $0.16^{\star \star}$ & $0.14^{\star \star}$ & $0.20^{\star \star \star}$ & $0.21^{\star \star *}$ & $0.23^{\star \star *}$ & $0.24^{\star \star *}$ & $0.15^{\star *}$ & 0.07 \\
\hline O-levels & $0.16^{\star * *}$ & 0.10 & 0.05 & $0.11^{\star *}$ & $0.11^{\star *}$ & $0.15^{\star \star \star}$ & $0.12^{\star}$ & 0.06 & 0.02 \\
\hline Other & 0.04 & 0.08 & 0.05 & 0.10 & $0.10^{*}$ & 0.10 & 0.11 & 0.06 & -0.07 \\
\hline Married & $0.07^{* *}$ & $0.08^{* *}$ & $0.08^{\star \star *}$ & $0.09^{\star \star *}$ & $0.09 * * *$ & $0.10^{\star \star \star}$ & $0.11^{* * *}$ & $0.09^{* * *}$ & $0.09^{* *}$ \\
\hline Managerial duties & 0.02 & 0.06 & $0.07^{\star \star}$ & $0.12^{\star \star \star}$ & $0.14^{\star * *}$ & $0.14^{\star \star *}$ & $0.15^{\star \star *}$ & $0.19^{\star * *}$ & $0.18^{* * *}$ \\
\hline \multicolumn{10}{|l|}{ Size of firm (ref: 200 or over) } \\
\hline Under 25 & $-0.23^{\star \star \star}$ & $-0.19^{\star \star *}$ & $-0.20^{\star \star \star}$ & $-0.22^{\star * *}$ & $-0.23^{\star \star \star}$ & $-0.22^{\star \star *}$ & $-0.22^{\star \star \star}$ & $-0.22^{\star * *}$ & $-0.13^{\star *}$ \\
\hline $25-199$ & $-0.08^{*}$ & $-0.08^{\star \star}$ & $-0.07^{\star \star}$ & $-0.10^{* \star *}$ & $-0.11^{\star \star \star}$ & -0.11 ** & $-0.11^{\star \star *}$ & $-0.11^{\star \star *}$ & -0.04 \\
\hline \multicolumn{10}{|c|}{ Occupational category (ref: elementary) } \\
\hline Managers & $0.41^{\star \star \star}$ & $0.46^{\star \star \star}$ & $0.54^{\star \star \star}$ & $0.50^{\star \star \star}$ & $0.52^{\star \star \star}$ & $0.50^{\star \star *}$ & $0.44^{\star \star *}$ & $0.43^{\star \star *}$ & $0.53^{\star \star *}$ \\
\hline Professionals & $0.42^{\star \star *}$ & $0.50^{\star \star \star}$ & $0.57^{\star \star *}$ & $0.56^{\star \star *}$ & $0.57^{\star \star \star}$ & $0.55^{\star \star *}$ & $0.47^{\star \star *}$ & $0.53^{\star \star *}$ & $0.57^{\star \star \star}$ \\
\hline Technicians and Ass Prof & $0.35^{\star \star *}$ & $0.34^{\star \star \star}$ & $0.42^{\star \star *}$ & $0.42^{\star * *}$ & $0.38^{\star \star *}$ & $0.35^{\star \star *}$ & $0.32^{\star \star *}$ & $0.39 * * *$ & $0.44^{\star * *}$ \\
\hline Admin/Secretarial & $0.30^{* \star *}$ & $0.34^{\star \star *}$ & $0.35^{\star \star *}$ & $0.30^{\star \star *}$ & $0.25^{\star \star *}$ & $0.19^{\star *}$ & $0.19^{\star}$ & $0.28^{* \star *}$ & $0.39^{* \star *}$ \\
\hline Skilled Trades & $0.18^{\star \star *}$ & $0.22^{\star \star \star}$ & $0.29^{\star \star *}$ & $0.28^{\star \star *}$ & $0.23^{\star \star *}$ & $0.21^{\star \star *}$ & $0.16^{\star \star \star}$ & $0.19 * \star *$ & $0.20^{\star \star \star}$ \\
\hline Personal Services & 0.04 & -0.02 & 0.02 & 0.08 & 0.10 & 0.09 & 0.18 & 0.08 & 0.36 \\
\hline Sales and customer serv. & -0.05 & 0.02 & 0.11 & 0.07 & 0.01 & 0.03 & -0.03 & 0.09 & 0.20 \\
\hline Operatives & $0.10^{*}$ & $0.12^{\star \star \star}$ & $0.17^{\star \star \star}$ & $0.16^{\star \star *}$ & $0.13^{\star \star \star}$ & $0.13^{\star \star}$ & $0.11^{* *}$ & $0.14^{\star \star \star}$ & $0.15^{\star *}$ \\
\hline Pseudo R-Square & 0.20 & 0.24 & 0.26 & 0.28 & 0.30 & 0.32 & 0.32 & 0.32 & 0.31 \\
\hline Number of observations & 1335 & & & & & & & & \\
\hline
\end{tabular}

\section{Panel (2)}

Women in the Private sector

\begin{tabular}{|c|c|c|c|c|c|c|c|c|c|}
\hline & $10 \%$ & $20 \%$ & $30 \%$ & $40 \%$ & $50 \%$ & $60 \%$ & $70 \%$ & $80 \%$ & $90 \%$ \\
\hline Constant & $1.37^{\star \star *}$ & $1.47^{\star \star \star}$ & $1.62^{\star \star \star}$ & $1.86^{\star \star \star}$ & $1.82^{\star \star \star}$ & $1.83^{* * *}$ & $1.85^{\star \star \star}$ & $1.82^{\star \star \star}$ & $1.90^{\star \star *}$ \\
\hline Work experience (years) & 0.01 & $0.03^{*}$ & 0.02 & 0.01 & $0.02^{\star}$ & $0.03^{\star \star}$ & $0.02^{\star \star}$ & $0.04^{\star \star \star}$ & $0.05^{\star \star \star}$ \\
\hline Work exp squared (x 1000) & -0.06 & -0.66 & -0.11 & 0.00 & -0.18 & -0.38 & -0.36 & $-0.83^{\star \star}$ & $-1.02 * *$ \\
\hline \multicolumn{10}{|c|}{ Highest level of education (ref: none) } \\
\hline Degree & 0.24 & $0.24^{*}$ & $0.23^{\star \star}$ & $0.26^{\star \star \star}$ & $0.33^{\star \star *}$ & 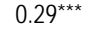 & 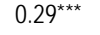 & $0.30^{\star \star \star}$ & $0.25^{\star \star}$ \\
\hline Other higher & 0.21 & 0.09 & 0.10 & 0.10 & $0.13^{\star \star}$ & 0.10 & 0.10 & $0.16^{\star}$ & 0.11 \\
\hline A-levels & 0.16 & 0.07 & 0.08 & 0.12 & $0.14^{*}$ & 0.10 & 0.05 & 0.05 & 0.03 \\
\hline O-levels & 0.14 & 0.04 & 0.06 & 0.06 & 0.08 & 0.07 & 0.03 & 0.04 & -0.03 \\
\hline Other & 0.15 & -0.01 & 0.06 & 0.06 & 0.03 & -0.00 & -0.02 & 0.03 & 0.01 \\
\hline Married & -0.03 & -0.11 ** & $-0.09 * \star$ & -0.04 & -0.05 & -0.05 & -0.02 & -0.07 & -0.06 \\
\hline Managerial duties & 0.03 & $0.09 * \star$ & $0.10^{\star \star \star}$ & $0.08^{* *}$ & $0.07^{\star \star}$ & $0.09 * \star$ & $0.14^{\star \star *}$ & $0.11^{\star \star}$ & $0.11^{\star *}$ \\
\hline \multicolumn{10}{|l|}{ Size of firm (ref: 200 or over) } \\
\hline Under 25 & $-0.29 * \star \star$ & $-0.24^{\star \star \star}$ & $-0.21^{\star \star \star}$ & $-0.23^{\star \star \star}$ & $-0.24^{\star \star \star}$ & 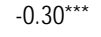 & $-0.28 * \star \star$ & $-0.26^{\star \star \star}$ & $-0.28^{* * *}$ \\
\hline 25-199 & -0.13 & $-0.15^{\star \star \star}$ & $-0.11^{\star *}$ & $-0.14^{\star \star \star}$ & $-0.13^{\star \star \star}$ & $-0.16^{\star \star \star}$ & $-0.14^{\star \star \star}$ & $-0.11^{\star \star}$ & $-0.12^{\star *}$ \\
\hline \multicolumn{10}{|c|}{ Occupational category (ref: elementary) } \\
\hline Managers & 0.37 & $0.37^{\star \star \star}$ & $0.45^{\star \star \star}$ & $0.48^{\star \star \star}$ & $0.47^{\star \star \star}$ & $0.49^{\star \star \star}$ & $0.56^{\star \star \star}$ & $0.73^{\star \star \star}$ & $0.86^{\star \star \star}$ \\
\hline Professionals & $0.57^{\star \star \star}$ & $0.53^{\star \star \star}$ & $0.67^{\star \star \star}$ & $0.68^{\star \star *}$ & $0.74^{\star \star \star}$ & $0.72^{\star \star \star}$ & $0.73^{\star \star \star}$ & $0.76^{\star \star \star}$ & 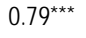 \\
\hline Technicians and Ass Prof & $0.36^{\star}$ & $0.46^{\star \star \star}$ & $0.53^{\star \star *}$ & $0.50^{\star \star *}$ & $0.48^{\star \star \star}$ & $0.46^{\star \star \star}$ & $0.52^{\star \star \star}$ & $0.55^{\star \star \star}$ & $0.61^{\star \star *}$ \\
\hline Admin/Secretarial & 0.20 & $0.33^{\star \star \star}$ & $0.35^{\star \star \star}$ & $0.35^{\star \star \star}$ & $0.29 \star \star \star$ & $0.26^{\star \star \star}$ & $0.27^{\star \star \star}$ & $0.27^{\star \star \star}$ & $0.29 * \star \star$ \\
\hline Skilled Trades & 0.12 & 0.11 & 0.13 & $0.17^{\star}$ & 0.12 & 0.09 & 0.06 & 0.03 & -0.03 \\
\hline Personal Services & 0.02 & 0.09 & 0.07 & $0.15^{\star \star}$ & $0.12^{\star}$ & $0.13^{*}$ & $0.13^{\star}$ & 0.14 & 0.14 \\
\hline Sales and customer serv. & -0.08 & 0.05 & $0.13^{*}$ & $0.11^{*}$ & 0.07 & 0.06 & 0.11 & $0.14^{*}$ & $0.21^{\star *}$ \\
\hline Operatives & 0.02 & 0.13 & $0.15^{\star}$ & $0.13^{*}$ & 0.08 & 0.07 & 0.11 & $0.16^{\star}$ & $0.17^{\star}$ \\
\hline Pseudo R-Square & 0.17 & 0.21 & 0.25 & 0.28 & 0.31 & 0.32 & 0.34 & 0.35 & 0.40 \\
\hline Number of observations & 624 & & & & & & & & \\
\hline
\end{tabular}

Source: British Household Panel Survey, Wave 15. Significant at $* \mathrm{p}<0.10 * * \mathrm{p}<0.05 * * * \mathrm{p}<0.01$.

Controls are included for region. 
Table 4.

Quantile Earnings Regressions for Men and Women in the Public Sector.

\begin{tabular}{|c|c|c|c|c|c|c|c|c|c|}
\hline \multirow[t]{2}{*}{ Panel (1) } & \multicolumn{9}{|c|}{ Men in the Public sector } \\
\hline & $10 \%$ & $20 \%$ & $30 \%$ & $40 \%$ & $50 \%$ & $60 \%$ & $70 \%$ & $80 \%$ & $90 \%$ \\
\hline Constant & $1.40^{\star \star \star}$ & $1.61^{\star \star \star}$ & $1.60^{\star \star \star}$ & $1.70^{\star \star \star}$ & $1.79^{\star \star \star}$ & $1.91^{\star \star \star}$ & $1.87^{\star \star \star}$ & $1.90^{\star \star \star}$ & $2.28^{\star \star \star}$ \\
\hline Work experience (years) & $0.04^{\star \star \star}$ & $0.03^{\star \star \star}$ & $0.04^{\star \star \star}$ & $0.03^{\star \star \star}$ & $0.03^{\star \star \star}$ & $0.02^{*}$ & $0.03^{\star \star}$ & $0.03^{\star *}$ & 0.01 \\
\hline Work exp squared (x 1000) & $-0.96^{\star \star}$ & $-0.78^{\star *}$ & $-1.03^{\star \star *}$ & $-0.79 * \star$ & $-1.00^{\star \star}$ & -0.51 & -0.61 & -0.62 & -0.04 \\
\hline \multicolumn{10}{|c|}{ Highest level of education (ref: none) } \\
\hline Degree & $0.33^{\star *}$ & $0.21^{*}$ & $0.19 *$ & $0.21^{*}$ & $0.17^{\star}$ & $0.23^{*}$ & $0.31^{\star *}$ & $0.38^{* *}$ & 0.23 \\
\hline Other higher & 0.18 & 0.12 & 0.08 & 0.11 & 0.08 & 0.07 & 0.12 & 0.16 & 0.01 \\
\hline A-levels & 0.18 & 0.13 & 0.12 & 0.20 & 0.12 & 0.09 & 0.11 & 0.26 & -0.01 \\
\hline O-levels & 0.00 & 0.12 & 0.06 & 0.12 & 0.07 & 0.07 & 0.09 & 0.17 & -0.03 \\
\hline Other & -0.11 & 0.11 & 0.10 & 0.12 & 0.02 & -0.03 & -0.04 & -0.02 & -0.25 \\
\hline Married & $0.17 * \star \star$ & $0.13^{\star *}$ & $0.13^{\star \star \star}$ & $0.13^{* \star *}$ & $0.12^{\star \star}$ & $0.12^{\star \star \star}$ & $0.14 * \star *$ & $0.15^{\star \star \star}$ & $0.20^{\star \star \star}$ \\
\hline Managerial duties & $0.13^{\star}$ & $0.16^{\star \star}$ & $0.13^{\star *}$ & $0.18^{\star \star \star}$ & $0.15^{\star \star \star}$ & $0.17^{\star \star \star}$ & $0.17^{\star \star *}$ & $0.20 * \star \star$ & $0.25^{\star \star \star}$ \\
\hline \multicolumn{10}{|l|}{ Size of firm (ref: 200 or over) } \\
\hline Under 25 & $-0.21^{*}$ & -0.09 & -0.10 & -0.04 & -0.06 & -0.06 & -0.00 & -0.03 & 0.02 \\
\hline $25-199$ & -0.04 & 0.02 & 0.00 & -0.02 & 0.00 & -0.04 & -0.03 & -0.06 & 0.02 \\
\hline \multicolumn{10}{|c|}{ Occupational category (ref: elementary) } \\
\hline Managers & 0.28 & $0.40^{\star \star *}$ & $0.47^{\star \star \star}$ & $0.47^{* * *}$ & $0.52^{\star * *}$ & $0.55^{\star \star *}$ & $0.53^{\star \star *}$ & $0.63^{\star \star *}$ & $0.62^{\star \star \star}$ \\
\hline Professionals & $0.36^{\star * *}$ & $0.42^{\star * *}$ & $0.49^{* * *}$ & $0.52^{\star \star *}$ & $0.58^{* * *}$ & $0.53^{* * *}$ & $0.53^{* * *}$ & $0.49^{* * *}$ & $0.54^{\star * *}$ \\
\hline Technicians and Ass Prof & 0.18 & $0.24^{\star *}$ & $0.28^{\star * \star}$ & $0.32 * * *$ & $0.36^{* * *}$ & $0.37^{\star * *}$ & $0.34^{\star * *}$ & $0.38 * * *$ & $0.36^{\star \star \star}$ \\
\hline Admin/Secretarial & 0.03 & -0.02 & 0.03 & 0.09 & 0.10 & $0.17^{*}$ & 0.14 & 0.14 & 0.13 \\
\hline Skilled Trades & 0.03 & -0.04 & -0.00 & 0.06 & 0.11 & 0.11 & 0.09 & 0.10 & 0.11 \\
\hline Personal Services & 0.09 & 0.05 & 0.05 & 0.01 & 0.02 & 0.02 & 0.03 & 0.09 & 0.16 \\
\hline Sales and customer serv. & & & & & & & & & \\
\hline Operatives & 0.06 & -0.06 & -0.01 & 0.08 & 0.12 & 0.10 & 0.09 & -0.01 & 0.04 \\
\hline Pseudo R-Square & 0.27 & 0.31 & 0.33 & 0.34 & 0.34 & 0.35 & 0.34 & 0.35 & 0.37 \\
\hline Number of observations & 412 & & & & & & & & \\
\hline
\end{tabular}

Panel (2)

Women in the Public sector

\begin{tabular}{|c|c|c|c|c|c|c|c|c|c|}
\hline & $10 \%$ & $20 \%$ & $30 \%$ & $40 \%$ & $50 \%$ & $60 \%$ & $70 \%$ & $80 \%$ & $90 \%$ \\
\hline Constant & 0.64 & $0.97^{\star \star}$ & $1.54^{\star \star \star}$ & $1.59 * * \star$ & $1.63^{* \star \star}$ & $1.65^{\star \star \star}$ & $1.94^{\star \star \star}$ & $2.08^{\star \star \star}$ & $1.82^{* \star \star}$ \\
\hline Work experience (years) & 0.02 & $0.03^{* *}$ & $0.03^{\star \star *}$ & $0.02^{\star \star}$ & $0.02^{\star *}$ & $0.02^{\star *}$ & $0.02^{\star \star}$ & 0.02 & $0.04^{\star * *}$ \\
\hline Work exp squared (x 1000) & -0.51 & $-0.85^{\star \star}$ & $-0.99 \star \star \star$ & $-0.70^{*}$ & -0.52 & $-0.54^{*}$ & -0.57 & -0.48 & $-1.12^{\star *}$ \\
\hline \multicolumn{10}{|c|}{ Highest level of education (ref: none) } \\
\hline Degree & 0.08 & 0.29 & 0.23 & $0.26^{\star \star}$ & $0.28 * \star$ & $0.30^{\star \star \star}$ & $0.29 * *$ & $0.35^{\star \star}$ & $0.36^{\star *}$ \\
\hline Other higher & 0.00 & 0.15 & 0.07 & 0.13 & 0.15 & $0.20^{*}$ & $0.20^{\star}$ & 0.19 & 0.18 \\
\hline A-levels & -0.02 & 0.18 & 0.10 & 0.16 & 0.16 & 0.16 & 0.11 & 0.16 & 0.16 \\
\hline O-levels & -0.06 & 0.05 & -0.00 & 0.04 & 0.06 & 0.06 & 0.05 & 0.08 & 0.07 \\
\hline Other & 0.03 & 0.05 & -0.03 & 0.10 & 0.10 & 0.21 & 0.17 & 0.16 & 0.29 \\
\hline Married & 0.04 & 0.04 & $0.06^{\star \star}$ & $0.06^{*}$ & 0.04 & 0.04 & 0.02 & -0.02 & -0.09 \\
\hline Managerial duties & $0.24^{\star \star \star}$ & $0.23^{\star \star \star}$ & $0.20^{\star \star \star}$ & $0.19^{\star \star *}$ & $0.18^{\star \star *}$ & $0.16^{\star \star \star}$ & $0.16^{\star \star \star}$ & $0.20^{\star \star *}$ & $0.17^{\star \star \star}$ \\
\hline \multicolumn{10}{|l|}{ Size of firm (ref: 200 or over) } \\
\hline Under 25 & 0.00 & -0.06 & $-0.09 *$ & -0.02 & -0.01 & -0.01 & -0.00 & -0.01 & 0.01 \\
\hline 25-199 & 0.07 & 0.03 & 0.01 & 0.03 & $0.05^{\star}$ & 0.01 & 0.02 & 0.02 & -0.01 \\
\hline \multicolumn{10}{|c|}{ Occupational category (ref: elementary and operatives) } \\
\hline Managers & $1.01^{\star \star}$ & $0.60^{\star}$ & 0.23 & 0.26 & 0.31 & $0.52^{*}$ & 0.34 & 0.31 & $0.48^{\star \star}$ \\
\hline Professionals & $1.38^{\star \star \star}$ & $0.98^{\star \star \star}$ & $0.61^{* \star}$ & $0.67^{\star \star \star}$ & $0.69^{\star \star *}$ & $0.71^{\star \star \star}$ & $0.49 * *$ & $0.40^{* *}$ & $0.58^{\star \star \star}$ \\
\hline Technicians and Ass Prof & $1.20^{\star *}$ & $0.74^{\star \star}$ & 0.35 & $0.39 *$ & $0.42^{*}$ & $0.47^{*}$ & 0.24 & 0.19 & $0.36^{\star *}$ \\
\hline Admin/Secretarial & $1.07^{\star \star}$ & 0.55 & 0.13 & 0.14 & 0.14 & 0.17 & -0.04 & -0.05 & 0.11 \\
\hline Skilled Trades & 0.64 & 0.09 & -0.32 & -0.27 & -0.26 & -0.22 & -0.38 & $-0.38^{*}$ & -0.16 \\
\hline Personal Services & $0.91^{\star *}$ & 0.45 & 0.08 & 0.10 & 0.10 & 0.14 & -0.08 & -0.11 & 0.03 \\
\hline Sales and customer serv & $0.91^{*}$ & 0.34 & 0.28 & 0.26 & 0.21 & 0.39 & 0.10 & 0.07 & 0.18 \\
\hline Pseudo R-Square & 0.31 & 0.34 & 0.37 & 0.38 & 0.39 & 0.39 & 0.38 & 0.35 & 0.32 \\
\hline Number of observations & 659 & & & & & & & & \\
\hline
\end{tabular}

Source: British Household Panel Survey, Wave 15. Significant at $\mathrm{p}<0.05 * * \mathrm{p}<0.01{ }^{* * *} \mathrm{p}<0.001$.

Controls are included for region. 
Figure 6a. The Log Wage Gap between Full-Time Men and Women Paid Like Men in the Public Sector.

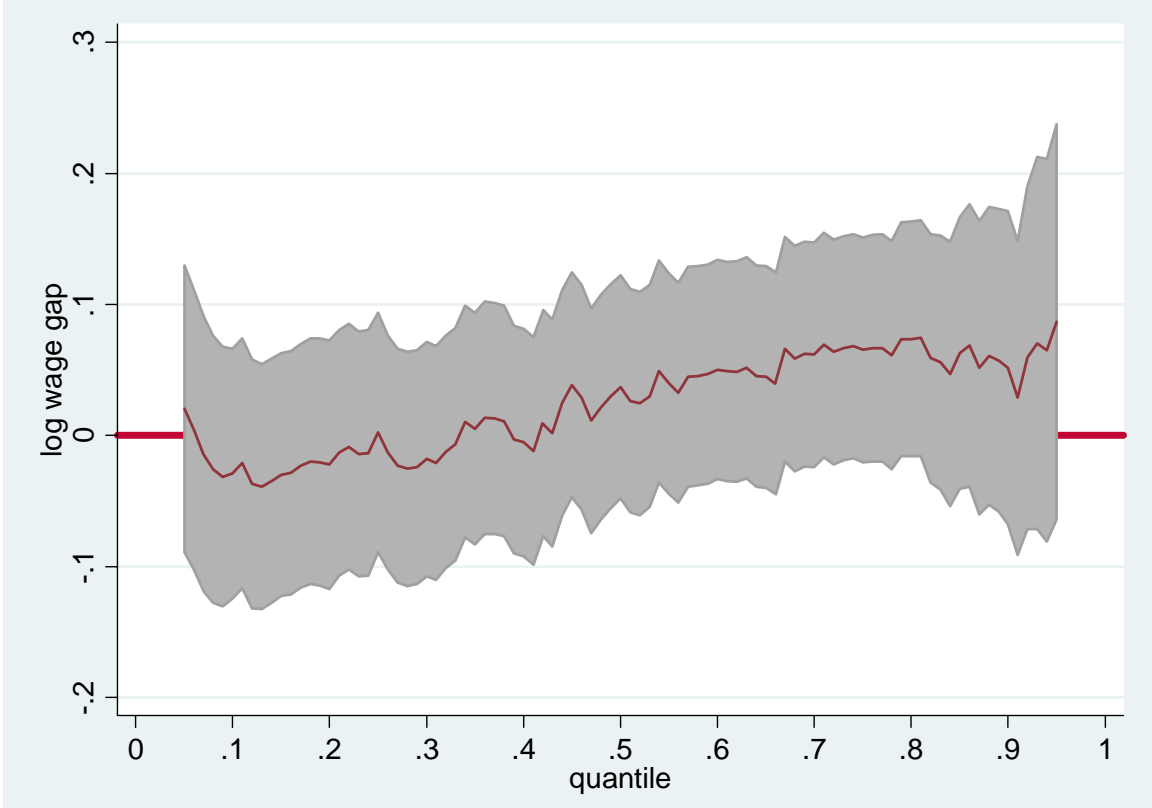

Figure 6b. The Log Wage Gap between Full-Time Men and Women Paid Like Men in the Private Sector.

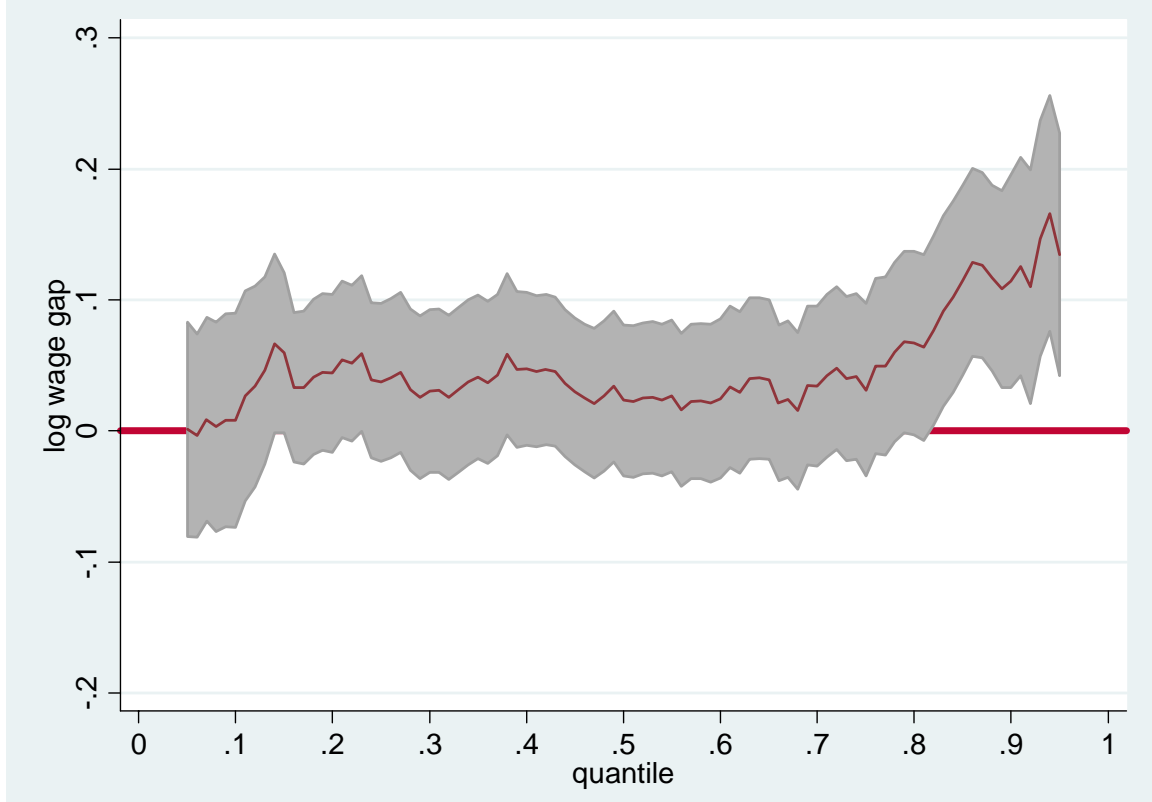


Figure 7a. Log Wage Gap between Full Time Men's Wages and the Wages that Women Would Earn if they had Men's Characteristics and Women's (Selection Adjusted) Returns in the Public Sector

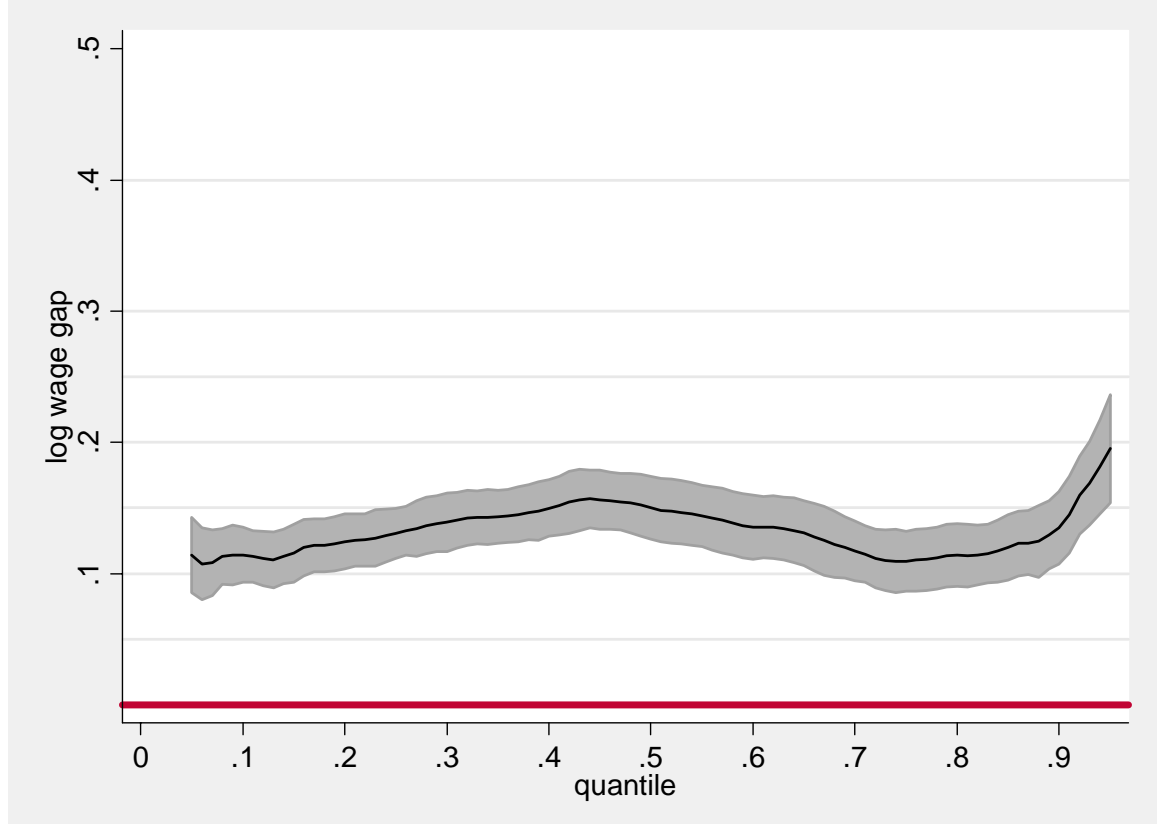

Figure 7b. Log Wage Gap between Full Time Men's Wages and the Wages that Women Would Earn if they had Men's Characteristics and Women's (Selection Adjusted) Returns in the Private Sector

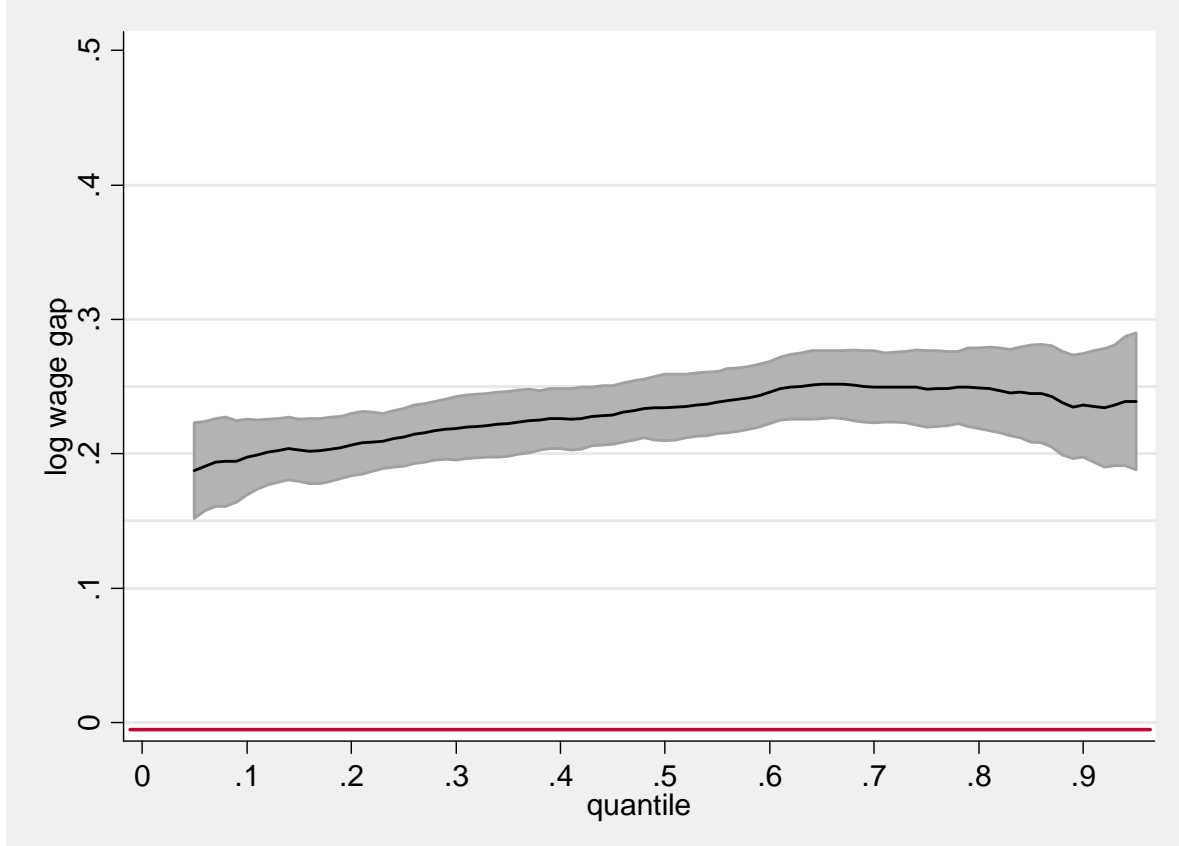




\section{Appendix.}

Table A1.

Descriptive Statistics for each Decile of Full-Time Men's Earnings Distribution in the Public Sector (column \%)

\begin{tabular}{|c|c|c|c|c|c|c|c|c|c|c|}
\hline & 1 & 2 & 3 & 4 & 5 & 6 & 7 & 8 & 9 & 10 \\
\hline Hourly wage (Mean, SD) & $\begin{array}{l}6.1 \\
(1.0)\end{array}$ & $\begin{array}{l}7.8 \\
(0.4)\end{array}$ & $\begin{array}{l}9.0 \\
(0.3)\end{array}$ & $\begin{array}{l}10.3 \\
(0.4)\end{array}$ & $\begin{array}{l}11.7 \\
(0.5)\end{array}$ & $\begin{array}{l}13.2 \\
(0.5)\end{array}$ & $\begin{array}{l}14.7 \\
(0.5)\end{array}$ & $\begin{array}{l}16.5 \\
(0.6)\end{array}$ & $\begin{array}{l}19.3 \\
(1.2)\end{array}$ & $\begin{array}{l}28.9 \\
(7.7)\end{array}$ \\
\hline $\begin{array}{l}\text { Work experience, years } \\
\text { (Mean, SD) } \\
\text { Highest level of education }\end{array}$ & $\begin{array}{l}10.27 \\
(7.00)\end{array}$ & $\begin{array}{l}13.03 \\
(8.59)\end{array}$ & $\begin{array}{l}12.02 \\
(6.10)\end{array}$ & $\begin{array}{l}11.70 \\
(7.22)\end{array}$ & $\begin{array}{l}11.23 \\
(5.60)\end{array}$ & $\begin{array}{l}11.95 \\
(6.42)\end{array}$ & $\begin{array}{l}12.04 \\
(6.92)\end{array}$ & $\begin{array}{l}13.27 \\
(6.44)\end{array}$ & $\begin{array}{l}12.34 \\
(5.59)\end{array}$ & $\begin{array}{l}13.54 \\
(5.57)\end{array}$ \\
\hline Degree & 9.5 & 17.1 & 17.1 & 26.8 & 20.9 & 47.5 & 51.2 & 48.8 & 63.4 & 68.3 \\
\hline Other higher & 42.9 & 39.0 & 43.9 & 46.3 & 67.4 & 30.0 & 39.0 & 31.7 & 34.2 & 26.8 \\
\hline A-levels & 9.5 & 9.8 & 17.1 & 0.0 & 4.7 & 10.0 & 4.9 & 14.6 & 2.4 & 2.4 \\
\hline O-levels & 16.7 & 24.4 & 12.2 & 22.0 & 2.3 & 7.5 & 4.9 & 4.9 & 0.0 & 2.4 \\
\hline Other & 11.9 & 4.9 & 0.0 & 4.9 & 2.3 & 2.5 & 0.0 & 0.0 & 0.0 & 0.0 \\
\hline None & 9.5 & 4.9 & 9.8 & 0.0 & 2.3 & 2.5 & 0.0 & 0.0 & 0.0 & 0.0 \\
\hline Married & 38.10 & 43.90 & 56.10 & 53.66 & 60.47 & 60.00 & 65.85 & 70.73 & 73.17 & 75.61 \\
\hline $\begin{array}{l}\text { Child(ren) present } \\
\text { Age of youngest child in } \\
\text { household }\end{array}$ & 28.57 & 21.95 & 48.78 & 43.90 & 37.21 & 42.50 & 43.90 & 53.66 & 56.10 & 51.22 \\
\hline 5 years or younger & 58.33 & 22.22 & 40.00 & 61.11 & 56.25 & 64.71 & 50.00 & 36.36 & 47.83 & 33.33 \\
\hline $6-11$ years & 25.00 & 44.44 & 45.00 & 11.11 & 25.00 & 29.41 & 33.33 & 36.36 & 26.09 & 47.62 \\
\hline $12-15$ years & 16.67 & 33.33 & 15.00 & 27.78 & 18.75 & 5.88 & 16.67 & 27.27 & 26.09 & 19.05 \\
\hline $\begin{array}{l}\text { Disagree that family suffers if } \\
\text { mother works full-time } \\
\text { Region }\end{array}$ & 35.71 & 39.02 & 39.02 & 46.34 & 41.86 & 60.00 & 43.90 & 36.59 & 34.15 & 31.71 \\
\hline South & 11.90 & 17.07 & 9.76 & 26.83 & 23.26 & 17.50 & 12.20 & 19.51 & 26.83 & 21.95 \\
\hline London & 4.76 & 0.00 & 0.00 & 7.32 & 9.30 & 12.50 & 9.76 & 2.44 & 4.88 & 12.20 \\
\hline East Midlands & 9.52 & 17.07 & 12.20 & 4.88 & 9.30 & 10.00 & 7.32 & 24.39 & 7.32 & 14.63 \\
\hline North & 19.05 & 24.39 & 12.20 & 12.20 & 16.28 & 20.00 & 19.51 & 19.51 & 21.95 & 19.51 \\
\hline Wales & 23.81 & 14.63 & 26.83 & 34.15 & 16.28 & 17.50 & 24.39 & 17.07 & 9.76 & 12.20 \\
\hline Scotland & 30.95 & 26.83 & 39.02 & 14.63 & 25.58 & 22.50 & 26.83 & 17.07 & 29.27 & 19.51 \\
\hline Managerial duties & 21.43 & 14.63 & 34.15 & 31.71 & 48.84 & 42.50 & 63.41 & 68.29 & 78.05 & 82.93 \\
\hline Size of firm & & & & & & & & & & \\
\hline Under 25 & 26.19 & 17.07 & 29.27 & 24.39 & 13.95 & 17.50 & 24.39 & 14.63 & 14.63 & 9.76 \\
\hline $25-199$ & 35.71 & 36.59 & 39.02 & 29.27 & 30.23 & 52.50 & 24.39 & 39.02 & 43.90 & 39.02 \\
\hline 200 or over & 38.10 & 46.34 & 31.71 & 46.34 & 55.81 & 30.00 & 51.22 & 46.34 & 41.46 & 51.22 \\
\hline Occupational category & & & & & & & & & & \\
\hline Managers & 4.76 & 0.00 & 4.88 & 2.44 & 4.65 & 12.50 & 12.20 & 19.51 & 24.39 & 29.27 \\
\hline Professionals & 2.38 & 9.76 & 2.44 & 7.32 & 20.93 & 27.50 & 29.27 & 34.15 & 53.66 & 48.78 \\
\hline $\begin{array}{l}\text { Technicians and Associate } \\
\text { Professionals }\end{array}$ & 16.67 & 12.20 & 26.83 & 36.59 & 41.86 & 45.00 & 46.34 & 34.15 & 17.07 & 21.95 \\
\hline Admin/Secretarial & 21.43 & 31.71 & 14.63 & 14.63 & 9.30 & 7.50 & 7.32 & 7.32 & 2.44 & 0.00 \\
\hline Skilled Trades & 16.67 & 19.51 & 12.20 & 17.07 & 11.63 & 5.00 & 2.44 & 2.44 & 2.44 & 0.00 \\
\hline Personal Services & 9.52 & 7.32 & 7.32 & 2.44 & 6.98 & 0.00 & 2.44 & 0.00 & 0.00 & 0.00 \\
\hline Sales and Customer Services & 0 & 0 & 0 & 0 & 0 & 0 & 0 & 0 & 0 & 0 \\
\hline Operatives & 7.14 & 2.44 & 9.76 & 12.20 & 0.00 & 2.50 & 0.00 & 2.44 & 0.00 & 0.00 \\
\hline Elementary & 21.43 & 17.07 & 21.95 & 7.32 & 4.65 & 0.00 & 0.00 & 0.00 & 0.00 & 0.00 \\
\hline No. observations $=412$ & & & & & & & & & & \\
\hline
\end{tabular}

Source: British Household Panel Survey, Wave 15. 
Table A2.

Descriptive Statistics for Each Decile of Full-Time Women's Earnings Distribution in the Public Sector (column \%)

\begin{tabular}{|c|c|c|c|c|c|c|c|c|c|c|}
\hline & 1 & 2 & 3 & 4 & 5 & 6 & 7 & 8 & 9 & 10 \\
\hline & 5.37 & 6.92 & 7.78 & 8.90 & 10.09 & 11.50 & 13.10 & 14.94 & 16.98 & 25.35 \\
\hline Hourly wage (Mean, SD) & $(0.91)$ & $(0.26)$ & $(0.27)$ & $(0.38)$ & $(0.31)$ & $(0.43)$ & $(0.55)$ & $(0.47)$ & $(0.97)$ & (11.45) \\
\hline Work experience, years & 11.10 & 9.79 & 11.63 & 11.46 & $9.44^{\prime}$ & 9.06 & 9.52 & 9.60 & 10.59 & 12.38 \\
\hline (Mean, SD) & (7.13) & $(5.61)$ & (6.22) & $(5.74)$ & $(6.81)$ & $(5.51)$ & $(6.47)$ & $(5.46)$ & $(5.54)$ & $(4.77)$ \\
\hline \multicolumn{11}{|l|}{ Highest level of education } \\
\hline Degree & 13.64 & 10.61 & 15.15 & 21.21 & 34.33 & 43.08 & 48.48 & 60.61 & 80.30 & 86.15 \\
\hline Other higher & 31.82 & 40.91 & 39.39 & 51.52 & 46.27 & 47.69 & 40.91 & 27.27 & 18.18 & 9.23 \\
\hline A-levels & 10.61 & 19.70 & 18.18 & 9.09 & 7.46 & 4.62 & 6.06 & 4.55 & 1.52 & 1.54 \\
\hline O-levels & 22.73 & 22.73 & 19.70 & 12.12 & 5.97 & 3.08 & 4.55 & 4.55 & 0.00 & 3.08 \\
\hline Other & 10.61 & 3.03 & 3.03 & 6.06 & 4.48 & 1.54 & 0.00 & 3.03 & 0.00 & 0.00 \\
\hline None & 10.61 & 3.03 & 4.55 & 0.00 & 1.49 & 0.00 & 0.00 & 0.00 & 0.00 & 0.00 \\
\hline Married & 54.55 & 59.09 & 59.09 & 65.15 & 44.78 & 53.85 & 40.91 & 45.45 & 63.64 & 61.54 \\
\hline Child(ren) present & 36.36 & 43.94 & 37.88 & 28.79 & 31.34 & 43.08 & 27.27 & 31.82 & 36.36 & 36.92 \\
\hline \multicolumn{11}{|l|}{$\begin{array}{l}\text { Age of youngest child in } \\
\text { household }\end{array}$} \\
\hline 5 years or younger & 12.50 & 20.69 & 36.00 & 26.32 & 42.86 & 39.29 & 27.78 & 33.33 & 41.67 & 25.00 \\
\hline $6-11$ years & 50.00 & 41.38 & 20.00 & 31.58 & 47.62 & 25.00 & 38.89 & 38.10 & 37.50 & 50.00 \\
\hline 12-15 years & 37.50 & 37.93 & 44.00 & 42.11 & 9.52 & 35.71 & 33.33 & 28.57 & 20.83 & 25.00 \\
\hline \multicolumn{11}{|l|}{ Disagree that family } \\
\hline $\begin{array}{l}\text { suffers if mother works full- } \\
\text { time }\end{array}$ & 36.36 & 36.36 & 51.52 & 53.03 & 58.21 & 55.38 & 53.03 & 60.61 & 57.58 & 61.54 \\
\hline \multicolumn{11}{|l|}{ Region } \\
\hline South & 10.61 & 19.70 & 12.12 & 13.64 & 10.45 & 10.77 & 19.70 & 22.73 & 15.15 & 18.46 \\
\hline London & 0.00 & 3.03 & 4.55 & 3.03 & 4.48 & 7.69 & 12.12 & 13.64 & 6.06 & 6.15 \\
\hline East Midlands & 18.18 & 9.09 & 9.09 & 19.70 & 11.94 & 9.23 & 10.61 & 7.58 & 16.67 & 16.92 \\
\hline North & 16.67 & 19.70 & 19.70 & 12.12 & 17.91 & 20.00 & 16.67 & 18.18 & 15.15 & 23.08 \\
\hline Wales & 25.76 & 30.30 & 37.88 & 22.73 & 22.39 & 26.15 & 16.67 & 15.15 & 10.61 & 9.23 \\
\hline Scotland & 28.79 & 18.18 & 16.67 & 28.79 & 32.84 & 26.15 & 24.24 & 22.73 & 36.36 & 26.15 \\
\hline Managerial duties & 16.67 & 15.15 & 19.70 & 31.82 & 41.79 & 49.23 & 53.03 & 48.48 & 51.52 & 76.92 \\
\hline \multicolumn{11}{|l|}{ Size of firm } \\
\hline Under 25 & 31.82 & 16.67 & 22.73 & 25.76 & 35.82 & 24.62 & 19.70 & 16.67 & 16.67 & 21.54 \\
\hline $25-199$ & 42.42 & 45.45 & 37.88 & 46.97 & 38.81 & 38.46 & 43.94 & 50.00 & 60.61 & 49.23 \\
\hline 200 or over & 25.76 & 37.88 & 39.39 & 27.27 & 25.37 & 36.92 & 36.36 & 33.33 & 22.73 & 29.23 \\
\hline \multicolumn{11}{|l|}{ Occupational category } \\
\hline Managers & 4.55 & 3.03 & 1.52 & 7.58 & 5.97 & 9.23 & 4.55 & 10.61 & 4.55 & 10.77 \\
\hline Professionals & 0.00 & 0.00 & 7.58 & 13.64 & 16.42 & 20.00 & 36.36 & 48.48 & 68.18 & 73.85 \\
\hline $\begin{array}{l}\text { Technicians and } \\
\text { Associate Professionals }\end{array}$ & 12.12 & 16.67 & 16.67 & 18.18 & 35.82 & 47.69 & 45.45 & 30.30 & 25.76 & 9.23 \\
\hline Admin/Secretarial & 25.76 & 50.00 & 43.94 & 34.85 & 28.36 & 13.85 & 12.12 & 7.58 & 1.52 & 4.62 \\
\hline Skilled Trades & 12.12 & 1.52 & 1.52 & 1.52 & 0.00 & 0.00 & 0.00 & 0.00 & 0.00 & 0.00 \\
\hline Personal Services & 34.85 & 25.76 & 28.79 & 24.24 & 7.46 & 7.69 & 1.52 & 3.03 & 0.00 & 1.54 \\
\hline $\begin{array}{l}\text { Sales and Customer } \\
\text { Services }\end{array}$ & 1.52 & 1.52 & 0.00 & 0.00 & 2.99 & 0.00 & 0.00 & 0.00 & 0.00 & 0.00 \\
\hline Operatives & 0.00 & 0.00 & 0.00 & 0.00 & 0.00 & 0.00 & 0.00 & 0.00 & 0.00 & 0.00 \\
\hline Elementary & 9.09 & 1.52 & 0.00 & 0.00 & 2.99 & 1.54 & 0.00 & 0.00 & 0.00 & 0.00 \\
\hline No. observations $=659$ & & & & & & & & & & \\
\hline
\end{tabular}

Source: British Household Panel Survey, Wave 15. 
Table A3.

Descriptive Statistics for Each Decile of Full-Time Men's Earnings Distribution in the Private Sector (column \%)

\begin{tabular}{|c|c|c|c|c|c|c|c|c|c|c|}
\hline & 1 & 2 & 3 & 4 & 5 & 6 & 7 & 8 & 9 & 10 \\
\hline \multirow{2}{*}{ Hourly wage (Mean, SD) } & 5.07 & 6.74 & 7.83 & 8.85 & 10.00 & 11.20 & 12.85 & 15.12 & 18.87 & 30.45 \\
\hline & $(0.99)$ & $(0.38)$ & $(0.27)$ & $(0.34)$ & $(0.32)$ & $(0.38)$ & $(0.54)$ & $(0.78)$ & $(1.54)$ & (10.02) \\
\hline \multirow{2}{*}{$\begin{array}{l}\text { Work experience, years } \\
\text { (Mean, SD) }\end{array}$} & 10.45 & 10.64 & 11.31 & 12.15 & 12.92 & 11.50 & 11.99 & 12.40 & 12.05 & 12.56 \\
\hline & (6.49) & $(6.70)$ & $(5.91)$ & (6.24) & $(6.90)$ & (6.12) & $(5.44)$ & $(5.96)$ & $(5.50)$ & $(4.86)$ \\
\hline \multicolumn{11}{|l|}{ Highest level of education } \\
\hline Degree & 8.21 & 3.76 & 8.96 & 7.52 & 11.19 & 14.81 & 13.64 & 26.32 & 37.50 & 54.96 \\
\hline Other higher & 24.63 & 39.10 & 48.51 & 39.10 & 51.49 & 45.19 & 47.73 & 45.86 & 46.32 & 26.72 \\
\hline A-levels & 14.18 & 18.80 & 6.72 & 14.29 & 14.18 & 13.33 & 12.12 & 9.77 & 10.29 & 10.69 \\
\hline O-levels & 26.12 & 17.29 & 19.40 & 23.31 & 15.67 & 19.26 & 20.45 & 12.03 & 2.94 & 6.11 \\
\hline Other & 8.21 & 9.02 & 6.72 & 8.27 & 4.48 & 4.44 & 3.03 & 3.76 & 2.21 & 0.76 \\
\hline None & 18.66 & 12.03 & 9.70 & 7.52 & 2.99 & 2.96 & 3.03 & 2.26 & 0.74 & 0.76 \\
\hline Married & 48.51 & 48.87 & 54.48 & 60.90 & 60.45 & 61.48 & 64.39 & 63.91 & 66.18 & 74.81 \\
\hline Child(ren) present & 37.31 & 40.60 & 35.07 & 45.11 & 47.76 & 42.96 & 50.76 & 45.11 & 48.53 & 54.20 \\
\hline \multicolumn{11}{|l|}{ Age of youngest child in } \\
\hline 5 years or younger & 62.00 & 42.59 & 55.32 & 41.67 & 45.31 & 51.72 & 55.22 & 55.00 & 51.52 & 61.97 \\
\hline $6-11$ years & 30.00 & 38.89 & 25.53 & 35.00 & 35.94 & 29.31 & 23.88 & 20.00 & 28.79 & 26.76 \\
\hline 12-15 years & 8.00 & 18.52 & 19.15 & 23.33 & 18.75 & 18.97 & 20.90 & 25.00 & 19.70 & 11.27 \\
\hline \multicolumn{11}{|l|}{ Disagree that family } \\
\hline $\begin{array}{l}\text { suffers if mother works full- } \\
\text { time }\end{array}$ & 41.04 & 36.09 & 37.31 & 45.11 & 38.06 & 33.33 & 37.88 & 35.34 & 41.91 & 37.40 \\
\hline \multicolumn{11}{|l|}{ Region } \\
\hline South & 11.94 & 15.04 & 21.64 & 22.56 & 19.40 & 17.04 & 21.97 & 24.06 & 28.68 & 32.06 \\
\hline London & 2.24 & 1.50 & 0.75 & 0.00 & 2.99 & 1.48 & 6.06 & 5.26 & 11.76 & 15.27 \\
\hline East Midlands & 17.91 & 14.29 & 18.66 & 22.56 & 21.64 & 20.74 & 19.70 & 18.05 & 17.65 & 12.21 \\
\hline North & 14.18 & 16.54 & 17.16 & 21.05 & 20.15 & 24.44 & 19.70 & 24.06 & 15.44 & 12.98 \\
\hline Wales & 27.61 & 24.81 & 22.39 & 13.53 & 11.94 & 17.78 & 15.91 & 13.53 & 7.35 & 7.63 \\
\hline Scotland & 26.12 & 27.82 & 19.40 & 20.30 & 23.88 & 18.52 & 16.67 & 15.04 & 19.12 & 19.85 \\
\hline Managerial duties & 23.13 & 27.07 & 28.36 & 33.83 & 37.31 & 45.19 & 47.73 & 52.63 & 72.79 & 85.50 \\
\hline \multicolumn{11}{|l|}{ Size of firm } \\
\hline Under 25 & 48.51 & 45.11 & 37.31 & 35.34 & 31.34 & 24.44 & 29.55 & 21.05 & 21.32 & 19.08 \\
\hline $25-199$ & 30.60 & 33.83 & 41.04 & 39.10 & 41.79 & 36.30 & 39.39 & 33.83 & 33.82 & 40.46 \\
\hline 200 or over & 20.90 & 21.05 & 21.64 & 25.56 & 26.87 & 39.26 & 31.06 & 45.11 & 44.85 & 40.46 \\
\hline \multicolumn{11}{|l|}{ Occupational category } \\
\hline Managers & 5.97 & 9.02 & 10.45 & 12.78 & 13.43 & 22.22 & 23.48 & 30.83 & 47.79 & 48.09 \\
\hline Professionals & 2.99 & 1.50 & 2.99 & 6.02 & 5.97 & 8.89 & 14.39 & 22.56 & 19.85 & 29.01 \\
\hline $\begin{array}{l}\text { Technicians and } \\
\text { Associate Professionals }\end{array}$ & 2.99 & 6.02 & 7.46 & 6.77 & 12.69 & 17.04 & 15.91 & 12.78 & 17.65 & 13.74 \\
\hline Admin/Secretarial & 1.49 & 5.26 & 3.73 & 9.02 & 2.99 & 4.44 & 2.27 & 2.26 & 2.21 & 3.05 \\
\hline Skilled Trades & 20.15 & 21.05 & 30.60 & 24.81 & 38.81 & 20.00 & 21.97 & 18.80 & 5.15 & 3.05 \\
\hline Personal Services & 3.73 & 0.00 & 0.75 & 0.00 & 1.49 & 0.00 & 0.76 & 0.00 & 1.47 & 0.00 \\
\hline $\begin{array}{l}\text { Sales and Customer } \\
\text { Services }\end{array}$ & 8.21 & 5.26 & 3.73 & 3.01 & 5.97 & 2.22 & 0.76 & 0.75 & 0.74 & 1.53 \\
\hline Operatives & 25.37 & 29.32 & 26.87 & 24.06 & 14.18 & 19.26 & 14.39 & 11.28 & 4.41 & 1.53 \\
\hline Elementary & 29.10 & 22.56 & 13.43 & 13.53 & 4.48 & 5.93 & 6.06 & 0.75 & 0.74 & 0.00 \\
\hline No. observations $=1335$ & & & & & & & & & & \\
\hline
\end{tabular}

Source: British Household Panel Survey, Wave 15. 
Table A4.

Descriptive Statistics for Each Decile of Full-Time Women's Earnings Distribution in the Private Sector (column \%)

\begin{tabular}{|c|c|c|c|c|c|c|c|c|c|c|}
\hline & 1 & 2 & 3 & 4 & 5 & 6 & 7 & 8 & 9 & 10 \\
\hline \multirow{2}{*}{ Hourly wage (Mean, SD) } & 4.19 & 5.59 & 6.31 & 6.91 & 7.74 & 8.70 & 9.96 & 11.57 & 14.00 & 24.22 \\
\hline & $(0.91)$ & $(0.28)$ & $(0.18)$ & $(0.22)$ & $(0.27)$ & $(0.31)$ & $(0.37)$ & $(0.56)$ & (1.17) & (7.94) \\
\hline Work experience, years & 9.71 & 10.03 & 8.57 & 10.68 & 9.67 & 10.26 & 11.17 & 10.97 & 10.42 & 11.98 \\
\hline (Mean, SD) & $(5.84)$ & $(4.90)$ & $(5.67)$ & $(5.87)$ & (5.13) & $(5.35)$ & $(6.26)$ & $(6.53)$ & $(5.89)$ & $(5.24)$ \\
\hline \multicolumn{11}{|l|}{ Highest level of education } \\
\hline Degree & 11.11 & 1.52 & 10.00 & 6.56 & 12.90 & 11.11 & 16.13 & 19.05 & 41.94 & 41.94 \\
\hline Other higher & 31.75 & 25.76 & 40.00 & 37.70 & 27.42 & 34.92 & 53.23 & 39.68 & 33.87 & 35.48 \\
\hline A-levels & 15.87 & 13.64 & 15.00 & 22.95 & 20.97 & 14.29 & 8.06 & 12.70 & 9.68 & 11.29 \\
\hline O-levels & 22.22 & 24.24 & 15.00 & 16.39 & 25.81 & 23.81 & 16.13 & 17.46 & 11.29 & 9.68 \\
\hline Other & 3.17 & 13.64 & 11.67 & 6.56 & 3.23 & 11.11 & 6.45 & 6.35 & 3.23 & 1.61 \\
\hline None & 15.87 & 21.21 & 8.33 & 9.84 & 9.68 & 4.76 & 0.00 & 4.76 & 0.00 & 0.00 \\
\hline Married & 60.32 & 45.45 & 58.33 & 59.02 & 43.55 & 44.44 & 51.61 & 39.68 & 50.00 & 58.06 \\
\hline Child(ren) present & 31.75 & 27.27 & 31.67 & 32.79 & 35.48 & 34.92 & 33.87 & 26.98 & 27.42 & 25.81 \\
\hline \multicolumn{11}{|l|}{$\begin{array}{l}\text { Age of youngest child in } \\
\text { household }\end{array}$} \\
\hline 5 years or younger & 35.00 & 33.33 & 31.58 & 35.00 & 31.82 & 27.27 & 57.14 & 17.65 & 29.41 & 31.25 \\
\hline $6-11$ years & 35.00 & 38.89 & 26.32 & 35.00 & 27.27 & 40.91 & 28.57 & 35.29 & 29.41 & 56.25 \\
\hline 12-15 years & 30.00 & 27.78 & 42.11 & 30.00 & 40.91 & 31.82 & 14.29 & 47.06 & 41.18 & 12.50 \\
\hline \multicolumn{11}{|l|}{ Disagree that family } \\
\hline $\begin{array}{l}\text { suffers if mother works full- } \\
\text { time }\end{array}$ & 42.86 & 48.48 & 63.33 & 49.18 & 56.45 & 61.90 & 46.77 & 55.56 & 61.29 & 58.06 \\
\hline \multicolumn{11}{|l|}{ Region } \\
\hline South & 12.70 & 19.70 & 15.00 & 16.39 & 27.42 & 26.98 & 20.97 & 23.81 & 38.71 & 30.65 \\
\hline London & 1.59 & 1.52 & 3.33 & 0.00 & 4.84 & 3.17 & 4.84 & 19.05 & 9.68 & 12.90 \\
\hline East Midlands & 17.46 & 13.64 & 15.00 & 19.67 & 17.74 & 20.63 & 19.35 & 7.94 & 11.29 & 12.90 \\
\hline North & 19.05 & 16.67 & 20.00 & 24.59 & 9.68 & 15.87 & 30.65 & 20.63 & 19.35 & 12.90 \\
\hline Wales & 23.81 & 15.15 & 28.33 & 6.56 & 17.74 & 11.11 & 9.68 & 11.11 & 11.29 & 8.06 \\
\hline Scotland & 25.40 & 33.33 & 18.33 & 32.79 & 22.58 & 22.22 & 14.52 & 17.46 & 9.68 & 22.58 \\
\hline Managerial duties & 30.16 & 30.30 & 35.00 & 37.70 & 41.94 & 42.86 & 45.16 & 52.38 & 56.45 & 87.10 \\
\hline \multicolumn{11}{|l|}{ Size of firm } \\
\hline Under 25 & 52.38 & 53.03 & 46.67 & 37.70 & 40.32 & 34.92 & 27.42 & 28.57 & 17.74 & 19.35 \\
\hline $25-199$ & 31.75 & 30.30 & 26.67 & 39.34 & 46.77 & 44.44 & 41.94 & 31.75 & 38.71 & 32.26 \\
\hline 200 or over & 15.87 & 16.67 & 26.67 & 22.95 & 12.90 & 20.63 & 30.65 & 39.68 & 43.55 & 48.39 \\
\hline \multicolumn{11}{|l|}{ Occupational category } \\
\hline Managers & 11.11 & 7.58 & 11.67 & 18.03 & 11.29 & 20.63 & 24.19 & 31.75 & 30.65 & 48.39 \\
\hline Professionals & 0.00 & 0.00 & 0.00 & 1.64 & 3.23 & 6.35 & 8.06 & 3.17 & 16.13 & 29.03 \\
\hline $\begin{array}{l}\text { Technicians and } \\
\text { Associate Professionals }\end{array}$ & 3.17 & 3.03 & 8.33 & 4.92 & 6.45 & 9.52 & 17.74 & 28.57 & 24.19 & 14.52 \\
\hline Admin/Secretarial & 14.29 & 7.58 & 21.67 & 29.51 & 35.48 & 28.57 & 30.65 & 31.75 & 19.35 & 4.84 \\
\hline Skilled Trades & 4.76 & 4.55 & 3.33 & 6.56 & 6.45 & 3.17 & 1.61 & 0.00 & 0.00 & 0.00 \\
\hline Personal Services & 19.05 & 15.15 & 18.33 & 11.48 & 12.90 & 6.35 & 4.84 & 1.59 & 3.23 & 0.00 \\
\hline $\begin{array}{l}\text { Sales and Customer } \\
\text { Services }\end{array}$ & 28.57 & 27.27 & 16.67 & 16.39 & 14.52 & 14.29 & 6.45 & 1.59 & 3.23 & 3.23 \\
\hline Operatives & 11.11 & 12.12 & 8.33 & 8.20 & 8.06 & 6.35 & 4.84 & 1.59 & 3.23 & 0.00 \\
\hline Elementary & 7.94 & 22.73 & 11.67 & 3.28 & 1.61 & 4.76 & 1.61 & 0.00 & 0.00 & 0.00 \\
\hline No. observations $=624$ & & & & & & & & & & \\
\hline
\end{tabular}

Source: British Household Panel Survey, Wave 15. 